\title{
Bütçe Kanununa Ekli Vergi Harcamaları Listesinin Mevzuatla Ücret Gelirlerine İlişkin Getirilen Muafiyet, İstisna ve İndirimler Bağlamında Analizi
}

İhami ÖZTÜRK, Department of Public Finance, Faculty of Economics and Administrative Sciences, Hacettepe University, Turkey; e-mail: ilhamiozturk@hacettepe.edu.tr

\author{
Analysis of the Tax Expenditures List Annexed to the Budget Act in the \\ Context of the Exceptions, Exemptions and Discounts that Pertain to Wages
}

\begin{abstract}
Tax is the most important resource used in order to finance public expenditures. From time to time, states abondon public financing preference and interviene in the economical and social life through tax. This interference happens through the tax expenditures consisting of tax exceptions, exemptions and discounts which result in loss of revenue for the state and which have, in reality, a similar impact on the public expenditures but these tax expenditures are different in their manner of execution. This study examines, in a comparative manner, the exceptions, exemptions and discounts applicable to wages under the relevant legislation and the list of tax expenditures annexed to the budget act and analyses whether the exceptions and privilages applicable to wages and which are not mentionned in the tax expenditures list represent a standard tax practice.
\end{abstract}

Keywords $\quad$ : Tax Expenditure, Wage, Exemption, Exception, Discount.

JEL Classification Codes : $\quad$ H27, K34.

\section{Öz}

Vergi, kamu harcamalarının finansmanında kullanılan en önemli kaynaktır. Devletler, zaman zaman kamu finansmanı tercihinden vazgeçerek, ekonomik ve sosyal hayata vergi aracılığıyla müdahalede ederler. Söz konusu müdahale, devletin gelir kaybına sebebiyet veren, vergi muafiyet, istisna ve indirimlerinden oluşan ve aslında kamu harcamalarına benzer bir etkiye sahip olmakla birlikte uygulanış biçiminde farklılıklar bulunan vergi harcamaları yoluyla gerçekleşir. Bu çalışmada, mevzuattaki ücretlere yönelik muafiyet, istisna ve indirimler ile bütçe kanunu ekindeki vergi harcamaları listesi karşılaştırmalı olarak irdelenmiş, vergi harcama listesinde yer verilmeyen ücretlere ilişkin vergi bağışıklık ve ayrıcalıklarının standart vergi uygulaması mahiyetinde olup olmadığı hususu analiz edilmiştir.

Anahtar Sözcükler Vergi Harcamas1, Ücret, Muafiyet, İstisna, İndirim. 


\section{Giriş}

Vergi harcamaları, belirli ekonomik ve sosyal amaçlara ulaşabilmek için standart vergi yapısından sapmak suretiyle mahrum kalınan vergi gelirleridir. Bilhassa bütçe disiplini açısından, vazgeçilen vergi tutarlarının olabildiğince net bir şekilde bilinmesi önemlidir. Böylece, vergi harcamalarının bütçe üzerindeki etkileri tam olarak irdelenebilecek ve gerektiğinde bu konuda fayda-maliyet analizi yapılabilecektir.

Ücret gelirlerinin vergilendirilmesi meselesi, günümüzde pek çok insanın ücret geliri elde etmesi ve yaşamlarını sürdürmede bu gelire bağlı olmaları nedeniyle üzerinde çokça tartışılan, siyasi ve ekonomik etkileri olan bir konu olma özelliğini sürdürmektedir. Çeşitli kanunlar ile özel sektör çalışanlarına ve kamu personeline yönelik, bazen her iki kesimi de aynı anda kavrayacak şekilde, muafiyet, istisna ve indirimler düzenlenmiştir. Bu vergi bağışıklık ve ayrıcalıkları, ayırma kuramına göre diğer gelir unsurlarına kıyasla vergilendirilmesi farklılık arz eden emek gelirlerini, elde edenlere önemli katkı ve firsatlar sunmaktadır. Ülkemizde ücret gelirlerine ilişkin vergi harcamaları ile ilgili çalışmaların sınırlı sayıda kaldığı, ücretlere ilişkin hangi muafiyet ve istisnaların vergi harcaması sayılacağı konusunda net bir belirleme bulunmadığ1, emek gelirlerine ilişkin vergi harcaması tutarlarının ayrı bir kalem olarak saptanmamış olduğu görülmektedir.

Çalışmamızda, yürürlükteki mevzuatta yer alan ücret gelirlerine yönelik vergi bağışıklık ve ayrıcalıkları tespit edilmiş, bunların bütçe kanunu ekinde yer alan vergi harcama listesinde mevcut olan vergi harcamaları ile karşılaştırması yapılmıştır. Bu karşılaştırma yapılırken, vergi harcamaları listesinde yer almayan bilhassa kamu personel ücretlerine yönelik vergi muafiyet ve istisnalarının standart vergi uygulaması niteliğinde olup olmadığ 1 hususu ile teorik olarak vergi harcaması niteliğindeki istisna ve muafiyetlerin bu listede yer almama gerekçeleri analiz edilmiştir.

\section{Vergi Harcaması}

\subsection{Vergi Harcaması Kavramı}

Ülkelerin ekonomik istikrarında büyük önem taşıyan kamu maliyesinin başarısında ön plana çıkan vergi, kamu harcamalarının finansmanında kullanılan en önemli araçtır (Starrett, 1988: 176). Devletler de bireyler gibi giderlerinin finansmanında değişik kaynaklar kullanırlar. Bu kaynakların en yaygın olanı vergilerdir (Mishkin, 1986: 351). Devlet tarafından yürütülen projelerin, yapılan yolların, binaların, parkların ve buna benzer tüm işlerin finansmanını sağlayan en büyük gelir yaratma mekanizması vergilerdir (Levinson, 2006: 50). Vergiler devletlerin bütçe politikalarında da önemli rol oynarlar (Freeland vd., 1996: 13-14). Devletlerin bütçe açıklarını kontrol altında tutabilmeleri etkin vergi politikaları sayesinde mümkündür (Abell \& Bernanke, 1994: 574-577). 
Vergi ödeme gücü bulunan kişilerin, güçleri doğrultusunda adaletli bir şekilde vergilendirilmesi esas kural olmakla birlikte, çeşitli nedenlerle bu kuralın dışına çıkılabilmektedir (Akdoğan, 2009: 48). Devletin vergi almasındaki amaç kamu harcamalarının finansmanı ile sınırlı değildir. Bazen kamu finansmanı tercihi bir kenara bırakılmak suretiyle ekonomik ve sosyal hayata müdahale amacı ön plana çıkarılabilmektedir.

Vergilerin, gelir artırmaktan ziyade farklı amaçlarla kullanılması, vergi teşviklerinin ortaya çıkmasına neden olmuştur (European Centre For The Development of Vocational Training, 2009: 18). Burada, modern maliyecilerin, vergi sisteminin temel prensiplerine ekledikleri yeni bir vergi prensibi karşımıza çıkmaktadır; "Vergilemede Müdahale Prensibi”. Bu prensip ile ekonominin normal işleyişi değiştirilmek, zaman zaman hızlandırılmak, ekonomide kaynak kullanımı iktisat politikasının amaçları doğrultusunda yönlendirilmek istenir (Türk, 2011: 129). Vergiler bu bağlamda ekonomik istikrarı kontrol altına almakta da önemli bir araç olarak karşımıza çıkmaktadır (Gruber, 2005: 6). Günümüzde, devletleri modern zamanın Robin Hood'u olarak tanımlamak mümkündür. Devletler vergi toplayıp, topladıkları bu vergiyi verimli kaynaklara aktararak topluma sosyal fayda sağlarlar ve gelir dağılımını daha adil hâle getirmeye çalışırlar (Slavin, 1999: 145).

Vergi harcamaları, vergi kanunlarında belirtilen, vergi indirimine veya devlet açısından vergi kaybına neden olan özel durumlardır (Mikesell, 1995: 409). Vergi harcaması (tax expenditure) kavramı 1960'lı yıllarda kullanılmaya başlanılmıştır. Bu kavramın yer aldığı ilk resmî belge ise 1974 yılı Amerika Birleşik Devletleri Bütçe Kanunu olarak kabul edilir. Adı geçen Kanun vergi harcamasını, federal vergi kanunlarında yer alan özel nitelikteki muafiyet, istisna, brüt gelirden indirim veya özel kredi, ayrıcalıklı vergi oranı, vergi ertelemesi sağlayan düzenlemelerden kaynaklanan gelir kayıpları olarak tanımlamıştır (Ferhatoğlu, 2005: 80). Buna göre, vergi harcamaları istisna, muafiyet veya safi gelirden indirim sağlayan durumları veya özel bir vadeyi, tercih edilen vergi oranını veya vergi ertelemesini içermektedir (Rosen, 1985: 353). Bir başka ifadeyle, vergi harcamaları, vergi kanunlarından bazı özel durumlarda geçerli olan vergi muafiyeti, indirimi, vade farklılaştırması ve diğer benzer vergi avantajlarını içerebilen devletin vergi kayıpları olarak adlandırılabilir (Gruber, 2005: 509). Vergi harcamasi; istisna ve muafiyetten daha geniş bir kavram olmakla birlikte istisna ve muafiyetle yakın ilişkisi vardır. Vergi harcaması yaygın olarak; belirli ekonomik ve sosyal amaçlara ulaşmak için oluşturulan ve gelir kayıplarını içeren, normal, standart veya genel kabul görmüş bir vergi yapısından ayrılma olarak tanımlanır (Erdem vd., 2013: 97). Vergi harcamaları, vergilendirilebilir gelir hesaplamasında oluşabilecek başarısızlıkları engellemek için kullanılmaktadır (Musgrave \& Musgrave, 1989: 352).

Vergi harcamaları devletlerin vergi gelirlerinde azalışa neden olmaktadır (Rosen, 1985: 366). Vergi harcamaları, hükümetlerin belli başlı faaliyetleri veya grupları cesaretlendirmek adına getirdiği teşvikler olarak da nitelendirilebilir. Örneğin, yatırımların bir kısmı vergiye tabi tutulmamakta, işsizlerin vergilendirilebilir gelirleri konusunda farklı 
uygulamalar yapılmaktadır. Vergi harcamaları, devletten özel sektöre herhangi bir fon akışını içermemekte, tam tersine mükelleflerin daha az vergi ödemeleri neticesinde devletin vergi gelirlerini düşürmektedir (Mikesell, 1995: 574-575). Benzer şekilde, vergi harcamaları veya indirimleri, mükelleflerin vergilendirilebilir gelirlerinin de düşmesine yol açar (Tresch, 2002: 346). Vergi gelirleri üzerinde azaltıcı etki doğuran, vergi kural ve standartlarından herhangi bir sapmaya veya düşmeye sebep olan her türlü konu, vergi harcaması adı altında anılmaktadır (Coşkun, 2010: 4).

IMF tarafından, vergi harcamalarının bir rapor olarak bütçe dokümanlarına eklemesi, mali saydamlığın temel gereği olarak nitelendirilmiştir. OECD ülkelerinin çoğunluğu düzenli olarak vergi harcamaları hakkında (genellikle yıllık) rapor yayımlamaktadırlar (Gönül, 2002: 68). Vergi harcaması kavramı, 5018 sayılı Kamu Mali Yönetimi ve Kontrol Kanunu ile ülkemizde ilk kez yasal bir dayanağa kavuşmuştur. Anılan Kanun'un, “Merkezî yönetim bütçe kanununun kapsamı” başlıklı 15'inci maddesinin 2'nci fikrasındaki; Merkezî yönetim bütçe kanununda; vergi muafiyeti, istisnası ve indirimleri ile benzeri uygulamalar nedeniyle vazgeçilen vergi gelirlerinin yer alacağı yönündeki hüküm ile vergi harcamalarının bütçe kanununda belirtilmesi zorunluluğu kurala bağlanmıştır ${ }^{1}$.

\subsection{Vergi Harcamalarının Hesaplanması ve Kamu Harcamaları ile Karşılaştırılması}

Vergi harcamaları, doğrudan yapılan kamu harcamalarında olduğu gibi, bir harcama türü olmasına rağmen, doğrudan harcamaların aksine, miktarının belirlenmesi ve bütçe sürecine dâhil edilmesi oldukça zordur. Bu konuda detaylı veri ve analizlere ihtiyaç duyulur (Y1lmaz, 2007: 17).

Vergi harcaması tutarını doğrudan hesaplamak için, ilk olarak vergi mevzuatındaki çeşitli vergi harcamalarının olmaması durumunda her birey ya da firmanın ödeyeceği vergi tutarı hesaplanır, daha sonra, elde edilen bu tutar ile fiilen ödenen tutar arasındaki fark bulunur, bulunan bu fark vergi harcaması dolayısıyla katlanılan vergi hâsılat kaybı olarak ifade edilir (Stiglitz, 1994: 38). Vergi harcamalarının tahmin edilmesinde üç yöntem kullanılmaktadır. Vazgeçilen gelir yöntemi; vergi ayrıcalıkları sebebiyle vergi gelirlerinde meydana gelen kayıpların ölçülmesidir. Kazanılan gelir yöntemi; vergi ayrıcalıkları kaldırıldığı zaman elde edilebilecek vergi kazancının tahmin edilmesidir.

1 Burada vergi harcaması aracı olarak muafiyet, istisna ve indirimler zikredilmiş, bunlara ek olarak "benzeri uygulamalar" denilmek suretiyle sayılan üç araç dışında da vergi harcaması aracı olabileceği hükme bağlanmıştır. Bir başka ifade ile, vergi harcaması türleri tadadî olarak belirlenmemiş, örnekleme yoluyla sayılanların dışında vergi harcaması türleri olabileceği belirtilmiştir. 
Eşdeğer harcama yöntemi; vergi harcaması yerine, aynı fayda düzeyine ulaşmak için yapılması gereken doğrudan kamu harcamaları tutarının tahmin edilmesini ifade eder (Maliye Bakanlığı Gelir Politikaları Genel Müdürlüğü, 2007: 6-7).

Devlet, bütçeden bir harcama yapmak yerine vergi harcaması gerçekleştirmek yoluyla da aynı sonuca ulaşabilir, ancak bu durumda uygulanan yöntem farklı olmaktadır. Örneğin, devletin üreticiye teçhizat alımı için mali yardım yapması hâlinde bu işlem kamu harcaması olarak resmî kayıtlara intikal etmekteyken, alım konusunda üreticiye vergi indirimi sağlanırsa üreticinin vergi borcu azalacak, ancak bu işlem kamu harcaması olarak görülmeyecektir (Stiglitz, 1999: 31).

Esasen doğrudan kamu harcaması yapmak ile aynı amaca vergi harcaması yaparak ulaşmak istenmesi arasında, devletlerin açık ve net kriterler belirlediğini söylemek mümkün değildir. Bunun sebebi vergi harcamalarının ortaya çıkması ve bunların harcama programı olduğu hususunun fark edilmesinin oldukça yeni bir geçmişe sahip olmasıdır (Surrey \& Mc Daniel, 1985: 27). Konu ile ilgili temel problem, vergi harcamaları ile ilgili basit bir tanım ışığında, vergi harcamalarını hesaplama yönteminin belirlenmemiş olmasıdır. $\mathrm{Bu}$ problem, ülkelerin kendi içerisinde ve ülkeler arasında vergi harcamalarının karşılaştırılmasını imkânsız hâle getirmektedir (Bratic, 2006: 113).

\section{3. Ücret Kavramı ve Ücret Gelirlerinin Vergilendirilmesi}

\section{1. Ücret}

Tam rekabet piyasasında ücret emeğin fiyatı olup diğer tüm fiyatlar gibi herhangi bir kontrole tabi olmaksızın belirlenir (Hicks, 1968: 1). Bu şekilde ödenen ücret aynı zamanda bir fiyattır. Ancak bu özellik ücretin pazar mekanizması kapsamında oluştuğu veya oluşmasının zorunlu olduğu anlamına gelmez. Zaten, ekonomide de sübvansiyonel fiyatlar gibi öyle fiyatlar vardır ki, bunlar da pazar mekanizmasına göre oluşmazlar (Balkan, 1976: 4). Ücret düzeyinin piyasa güçlerine bağlı olduğunu ve emek talep ve arz eğrilerinin karşılaşması sonucu belirleneceğini vurgulayan tam rekabet teorisi modeline karşı modern ekonomi, işverenlerle çalışma konularını ve ücret oranlarını müzakere eden sendikal müdahaleleri göz önünde tutmaktadır (Parasız, 1994: 111).

Ücret kavramının doğuşu 13. yüzyıl sonlarına rastlar. O günlere dek kölelik geçerli olduğundan ücret söz konusu değildir. Çağdaş ücret kavramının ortaya çıkması ise, endüstri devrimiyle birlikte olmuştur. Çağdaş anlamda ücret parasal bir değerdir. Endüstri devriminden önce ücretler aynî nitelikte idi. Gerçi çağdaş anlamdaki ücretin içinde aynî nitelikte ödemeler de bulunur, ancak ücretin çok büyük bir bölümü parasal niteliktedir (Korkmaz vd., 1985: 10). Ücret, çalışanlar için bir gelir, çalıştıranlar için ise bir maliyet unsuru olduğu için, eskiden beri iş̧̧i işveren uyuşmazlıklarının odak noktası olmuştur (Gerek, 1999: 7). Ücret gelirleri; bölgelere, endüstrilere ve mesleklere göre oldukça büyük 
farklılıklar göstermektedir (Wolf vd., 1965: 22). Emeğin karşılığg olan ücret zamanla çeşitli düşüncelere dayalı olarak yeni içerikler kazanmıştır. Günümüzde ücretli çalışma pek çok insanın ve ailesinin tek gelir kaynağıdır. Ücret, bir taraftan emeği karşılığında çalışanların gelirlerini ve yaşam düzeylerini belirleyici bir unsur, diğer taraftan gerek ekonominin gelişmesine etki eden bir maliyet unsuru, gerekse millî gelirin çeşitli gelir gurupları arasındaki dağılım tarzını, o toplumdaki sosyal adaletin durumunu ortaya koyan bir gösterge olarak çok yönlü bir içerik taşımaktadır (Çakır, 2006: 1).

\section{2. Ücret Gelirlerinin Vergilendirilmesi}

Gelir Vergisi Kanunu'nun 2'nci maddesinde gelire giren ve yedi kategori halinde sayılan kazanç ve iratlar arasında "ücretler" de yer almaktadır. Ücretler, aynı Kanun'un 61'inci ve devamı maddeleri uyarınca vergilendirilmektedir. Ücret gelirlerinin vergilendirilmesinde, esas olan Gelir Vergisi Kanunu'nun 61'inci maddesinde ${ }^{2}$ yer alan tanımdır. Bu tanım, vergi tekniğgi açısından başarılı bir tanım olarak ücret gelirlerinin tamamını kapsamına almaya yetecek niteliktedir.

Bir ödemenin ücret olarak nitelendirilebilmesi için üç özelliğe aynı anda sahip olması gerekir. Birincisi, hizmetin işverene tabi olarak verilmesi gerekir. Ücrette, işverenle hizmet erbabı arasında bağlılık ilişkisi vardır. Hizmet erbabının yaptığı çalışma kendi adına değil; işverenin adına ve işverenin çizdiği sınırlar içinde yapılmaktadır. İkincisi, hizmetin bir işyerine bağlı olarak yapılmasıdır. Hizmet erbabı emeğini, işveren tarafından gösterilecek belirli bir işyerinde sunmak zorundadır. Bazı durumlarda hizmetin mutlaka bir işyerinde yapılması gerekmez. İşverene hukuken bağlı olmak yeterlidir. Üçüncü olarak da, ödemenin hizmet karşılığı yapılmasıdır (Kızılot \& Taş, 2011: 238). Ücret gelirinin özelliği emek karşılığı elde edilmiş ya da emek ağırlıklı olarak yürütülen faaliyetlerden doğmuş olmasıdır. Bir hukukî betimleme yapmak gerekirse, emek gelirleri kategorisindeki kazançlar iş görme akitlerinin icrasından doğmaktadır. Üretime katılan emek bedensel ya da zihinsel olabilir. Bir hizmet akdî ile işverene bağımlı olarak çalışma karşılığ 1 elde edilen gelir, kanuna göre ücret sayılmıştır. Kısaca nitelersek, ücret bağımlı emeğin gelirini oluşturur. Bir istisna ya da vekâlet akdi çerçevesinde, belli bir öğrenime ve uzmanlığa dayanan uzmanlaşmış emeğin ağırlıklı yer aldığ 1 bir faaliyetten doğan gelir ise serbest meslek kazanc1 olarak adlandırılır. (Öncel vd., 2013: 243, 288). Hizmetle ilişkisi olmayan, hiç bir emek

2 Gelir Vergisi Kanunu'nun "Ücretin Tarifi”" başllkll 61 'inci maddesinde; "Ücret, işverene tabi belirli bir işyerine bağlı olarak çalışanlara hizmet karşıllğg verilen para ve ayınlar ile sağlanan ve para ile temsil edilebilen menfaatlerdir. Ücretlerin ödenek, tazminat, kasa tazminatı (Mali sorumluluk tazminatl), tahsisat, zam, avans, aidat, huzur hakkl, prim, ikramiye, gider karşıllğ̆ veya başka adlar altında ödenmiş olması veya bir ortakllk münasebeti niteliğinde olmamak şartı ile kazancın belli bir yüzdesi şeklinde tayin edilmiş bulunması onun mahiyetini değişstirmez." hükmü yer almaktadır. 
sunumunun karşılığı olmayan ödemeler ücret sayılamaz. Bunlar başka bir üretim etkeninin kullanılması karşılığında yapılmamışsa, ücretten alınan gelir vergisine tabi değildir, bağıştır, ihsandır, yardımdır. Eğer işveren ile işgören arasında bir iş akdi ya da toplu sözleşme varsa, bu kişiye yapılan bütün ödemelerin ücret olarak vergi kesintisine tabi olduğu varsayımı yapılır (Bulutoğlu, 2004: 47).

Ücretin ödenek, tazminat, kasa tazminatı (mali sorumluluk tazminatı), tahsisat, zam, avans, aidat, huzur hakkı, prim, ikramiye, gider karşıllı̆ı veya başka adlar altında ödenmiş olması veya bir ortaklık ilişkisi niteliğinde olmaması şartı ile kazancın belli bir yüzdesi şeklinde tespit edilmiş olması, ücretin niteliğini değiştirmez. Böylece kanun, terminoloji kargaşasının uygulamada tereddüt yaratmasını engellemek istemektedir. Ayrıca arada bir ortaklık ilişkisinin bulunmadığı durumlarda, ücretin kazancın belli bir yüzdesi olarak kararlaştırılmış bulunması da aynı esasa bağlanmıştır. Başka bir anlatımla, bu durumda da diğer koşulların varlığıyla birlikte, ücret gelirine hak kazanma ve ona göre vergilendirme geçerli olacaktır (Öncel vd., 2013: 289). İşveren ile işçi arasındaki edimler mutlaka bir hizmet ya da iş sözleşmesi yapmayı gerektirmez. Kamu kesiminde ücretlilerin hak ve görevleri doğrudan doğruya yasalar ${ }^{3}$ ve tüzüklerle belirlenir (Bulutoğlu, 2004: 46). Bu noktada, Gelir Vergisi Kanunu açısından ücret gelirlerinin vergiye tabi olmasında, ücretin kamu ya da özel kesim çalışanları tarafından elde edilmesi arasında fark yoktur.

Ücretin elde edilmesi, tahsil esasına bağlanmıştır. Dolayısıyla vergi, ücretin tahsil edilmesi durumunda söz konusu olur. Ücretin, hizmet erbabına daha önce yaptığı veya gelecekte yapacağı hizmetler karşılığında verilmesi önemli değildir (Arslan, 2004: 70).

3 Nitekim Anayasa'nın 128 'inci maddesinin 2 'nci fikrasında; memurların ve diğer kamu görevlilerinin nitelikleri, atanmaları, görev ve yetkileri, hakları ve yükümlülükleri, ayllk ve ödenekleri ve diğer özlük işlerinin "kanunla" düzenleneceği hüküm altına alınmış̧ır. Bir işyerinde ya da bir devlet örgütünde, yasalar ve sözleşme uyarınca, yöneticinin emir ve kumandasında, bağıml emek hizmeti sunularak kazanılan gelir devlette "maaş", piyasada ise "ücret”" olarak adlandırllır (Bulutoğlu, 2004: 45). 657 sayll Devlet Memurları Kanunu'nun 147'nci maddesinde; bu kanuna tabi kurumlarda görevlendirilen Devlet memurlarına hizmetlerinin karşılığında, kadroya dayanılarak ay itibarıyla ödenen para "ayllk" olarak tanımlanmıştır. Türk mali mevzuatında genellikle aylık (maaş) kelimesi memurların gelirleri için kullanıldığı halde ücret kelimesi işçilerin gelirlerini ifade etmek üzere kullanılır. Memurlara ayllkları her ay peşin olarak ödenir. Emeklilik ve ölüm hallerinde o aya ait peșin ödenen ayllk geri alınmaz (Öncel ve Çağan, 2003: 136). Maaş (ayllk) ücret kavramindan farklı bir kavramdır. $\ddot{U}$ cret bir kişinin yaptığ iş̧in karşılığı olduğu halde maaş memurun yaptığ işin karşsllğ göreve denk düşecek bir sosyal düzeyde yaşama imkânı sağlamaya yönelik parasal bir araçtır. Maaş yapılan işin değil işgal edilen memuriyetin karşıllğ̆ıdır. Maaş "statüter" niteliktedir. Kanun ve düzenleyici işlemlerle düzenlenir. Maaşın miktarl idare tarafindan tek yanl olarak belirlenir (Gözler, 2009: 744). Kaтu hukuku kapsamında, maaş ile ücret arasındaki bu farklllklar memurlar ve diğer kamu görevlilerine yapılan ödemelerin Gelir Vergisi Kапипи kapsaminda ücret geliri olarak vergilendirilmesini engellemez. 
Ücret geliri elde eden açısından talep edilebilir hale geldiği durumda, elde etmenin gerçekleştiği kabul edilmektedir (Öz, 2006: 120).

Gelir Vergisi Kanunu'nun 61'inci maddesinde yazılı ödemelerin ${ }^{4}$ de bu Kanun'un uygulanmasında ücret sayılacağı hükme bağlanmıştır.

Kanun koyucu açıkça gösterilmediği takdirde vergi dışı kalabilecek bazı ödemeleri, nitelikleri gereği en yakın gelir unsuru içinde mütalaa edip aynı şekilde vergilendirilmesini istediğinde, bu amaca uygun olarak açıkça belirleme yoluna gitmektedir. Bunun yanı sıra, Gelir Vergisi Kanunu kapsamına girmekle birlikte, gelir türü olarak niteliği tartışmaya açık bir kazanç belli bir kategori içine sokulduğunda hem tartışmalar giderilmiş olmakta hem de o kazanç unsuru vergilendirme tekniği, istisnalar vb. açısından, dâhil edildiği kategorinin statüsüne tabi olmaktadır. Gerçekten ücret sayılacağı belirtilen gelir unsurları incelendiğinde bunların ücret olup olmadıkları konusunda şüpheler ortaya çıkmaktadır. Milletvekillerinin aylıkları düşünüldüğünde bağımlı olarak çalışma ilişkisinin bu statüde geçerli bulunmaması nedeniyle ödemenin ücret olarak vergilendirilip vergilendirilemeyeceği uyuşmazlık konusu olabilir. Bilirkişi ücretleri için de aynı esas geçerlidir (Özel \& Şenyüz, 1987: 82; Öncel vd., 2013: 290).

Gelir Vergisi Kanunu ücret gelirlerinin vergilendirilmesinde bir başka söyleyişle matrahın tespitinde "gerçek usul" ve "diğer ücretler" olmak üzere iki usul kabul etmiştir. Ücret gelirlerinin vergilendirilmesinde ilke olarak gerçek usul kabul edilmiştir5 ${ }^{5}$ Vergi,

4 Ücret sayılacağ belirtilen ödemeler şunlardır: Kanunla kurulan emekli sandıkları ile 506 sayll Sosyal Sigortalar Kanunu'nun geçici 20 'nci maddesinde belirtilen bankalar, sigorta ve reasürans şirketleri, ticaret odalarl, sanayi odaları, borsalar veya bunların teşkil ettikleri birliklerin personellerinin malullük, yaşllllk ve ölümlerinde yardım yapmak üzere kurulan sandlklardan ödenen ve en yüksek devlet memuruna ödenen tutar aşan emeklilik, maluliyet, dul ve yetim aylıkları; evvelce yapılmış veya gelecekte yapılacak hizmetler karşılı̆̆ında verilen para ve ayınla sağlanan menfaatler; Türkiye Büyük Millet Meclisi, il genel meclisi ve belediye meclisi üyeleri ile özel kanunlarına veya idari kararlara göre kurulan daimi veya geçici bütün komisyonların üyelerine ve yukarlda sayllanlara benzer diğer kişilere bu sifatlarl dolaylsiyla ödenen veya sağlanan para, ayın ve menfaatler; yönetim ve denetim kurullar başkan ve üyeleri ile tasfiye memurlarına bu sifatlarl dolaylsıyla ödenen veya sağlanan para, ayın ve menfaatler; bilirkişilere, resmi arabuluculara, eksperlere, spor hakemlerine ve her türlü yarlşma jürisi üyelerine ödenen para, sağlanan ayın ve menfaatler; sporculara transfer ücreti veya sair adlarla yapılan ödemeler ve sağlanan menfaatler.

5 Hizmet erbabına ödenen ücretler ile Kanun gereğince ücret sayılan ödemelerden tevkifat yapılır (Gelir Vergisi Kanunu, md.94). Issverenler, hizmet erbabına ödedikleri ücretlerden 94 'üncü madde gereğince yaptıklarl vergi tevkifatını Vergi Usul Kanunu'nda yazılı ücret bordrosunda veya bordro yerine geçen diğer kayıtlarda göstermeye mecburdur (Gelir Vergisi Kanunu, md.97). Tevkifata tabi olmayan ücretler Gelir Vergisi Kanunu'nun 95 'inci maddesinde belirtilmişstir. Bu ücretler yıllık beyanname ile bildirilir. Tek işverenden alınmış ve tevkif suretiyle vergilendirilmiş ücretler için ylllk beyanname verilmez, diğer gelirler için beyanname verilmesi halinde bu gelirler beyannameye dahil edilmez. Birden fazla işverenden ücret almakla beraber, birden sonraki işverenden aldıkları ücretlerin toplamı, Gelir Vergisi Kanunu'nun 103 'üncü maddesinde yazll tarifenin 
gelirin gerçek ve safi tutarı üzerinden alınmaktadır. Gelir Vergisi Kanunu'nun 63'üncü maddesi uyarınca ücretin gerçek safi değeri, ücretin tanımında yer alan menfaatler toplamından belirtilen indirimlerin ${ }^{6}$ yapılması sureti ile hesaplanır.

Bazı işlerde çalışanların, ücret gelirlerinden dolayı diğer usule göre vergilendirilmesi ${ }^{7}$ kabul edilmiştir. Götürü usul olarak da nitelendirilebilecek bu usulde gerçek ücret tutarı dikkate alınmaksızın asgari ücretten yararlanılarak gelir vergisi tespit edilmektedir (Kızılot \& Taş, 2011: 238). Diğer ücretler için yıllık beyanname verilmesine gerek yoktur. Ayrıca, Gelir Vergisi Kanunu'nun 64'üncü maddesine göre, başka gelirler nedeniyle beyanname verilmesi halinde de diğer ücretler beyannameye dâhil edilmeyecektir.

\section{4. Ücretlere Yönelik Muafiyet, İstisna ve İndirimler ile Vergi Harcamaları Listesinin Karşılaştırııması ve Analizi}

Vergi harcamalar1; muafiyet, indirim, istisna, indirimli vergi oranlar1, vergi ertelemeleri ve gelir vergisindeki vergi tevkifatı yapılmamış ve belli tutarı aşmayan bazı gelirlerin beyan dahi edilmemesi şeklindedir (Pedük, 2005: 92). Vergi mevzuatında vergi harcamaları ağırlıklı olarak; vergi istisnası, vergi muafiyeti ve vergi indirimleri olarak karşımıza çıkmaktadır (Akdoğan, 2007: 173). Buna benzer şekilde "ücret" gelirlerine yönelik vergi harcamaları da mevzuatımızda muafiyet, istisna ve indirim şeklinde düzenlenmiştir. Gelir Vergisi Kanunu'nda; "Diplomat Muaflı̆̆l", "Ücret İstisnası", "Müteferrik İstisnalar", "Tazminat ve Yardimlar", "Vatan Hizmetleri Yardımları", "Teçhizat ve Tayın Bedelleri" ve "Teşvik İkramiye ve Mükâfatları" başlılları altında muafiyet ve istisnalar, "Engellilik İndirimi" ve "Asgari Geçim İndirimi" başlıkları altında

ikinci gelir diliminde yer alan tutarı aşmayan mükelleflerin, tamamı tevkif suretiyle vergilendirilmiş ücretleri için de beyanname verilmez (Gelir Vergisi Kanunu, md.86).

6 Bu indirimler şunlardır: 657 sayll Devlet Memurları Kanunu'nun 190'incı maddesi uyarınca yapılan kesintilerle, Ordu Yardımlaşma Kurumu ve benzeri kamu kurumları için yapılan kanuni kesintiler; kanunla kurulan emekli sandıklart ile 506 Sayll Sosyal Sigortalar Kanunu'nun geçici 20 'nci maddesinde belirtilen sandıklara ödenen aidat ve primler; 5510 sayll Sosyal Sigortalar ve Genel Sağllk Sigortası Kanununa göre hesaplanarak iş̧̧iden kesilen sosyal güvenlik destekleme primi; mükellefin şahsina, eşine ve küçük çocuklarına ait özel sigortalar için hizmet erbabı tarafindan ödenen primler ile bireysel emeklilik sistemine ödenen katkr paylarl; aidatın ödendiğinin belgelendirilmesi şartıyla, çalışanlar tarafindan ilgili kanunlara göre sendikalara ödenen aidatlar. Ayrica, Gelir Vergisi Kanunu'nun 63'üncü maddesinde yer almamakla birlikte 4447 sayll İssizlik Sigortası Kanunu'nun 49 'uncu maddesinin 4'üncü fikrası gereğince işsizlik sigortasina sigortalılarca ödenen işsizlik sigortası primleri de gerçek ücretin hesaplanmasında gelir vergisi matrahından indirilir.

7 Gelir Vergisi Kanunu'nun 64'üncü maddesi uyarınca; kazançları basit usulde tespit edilen ticaret erbabının yanında çalışanlar, özel hizmetlerde çalışan şoförler, özel inşaatlarda çalıştırllan işçiler, gayrimenkul sermaye iradı sahibinin yanında çalışanlar, gerçek ücretlerinin tespitine imkân olmaması sebebiyle bu kapsama alınanların, safi ücretleri takvim yll başında geçerli olan ve sanayi kesiminde çalışan on altı yaşından büyük işçiler için uygulanan asgari ücretin yıllık brüt tutarının \%25 'idir. 
da indirimler düzenlenmiştir. Ayrıca, Gelir Vergisi Kanunu'nun 63'üncü maddesinde, ücretin gerçek safi değerine ulaşmak için yapılacak “indirimler” sayılmıştır.

Gelir Vergisi Kanunu dişındaki kanunlarda yer alan ücretlere yönelik vergi harcamalarının da genellikle muafiyet ve istisna şeklinde düzenlendiğini söylemek mümkündür.

Gerek vergi istisnası gerekse vergi muafiyetinden söz edilebilmesi için öncelikle o konu ya da kişinin vergi kapsamına alınmış olması gerekirken, ancak bundan sonra vergi konusunun kısmen ya da tamamen vergiden istisna tutulması ya da bazı kişi ya da grupların vergiden muaf tutulması mümkün olabilecektir (Akdoğan, 2009: 48). Bir başka şekilde ifade etmek gerekirse, zaten vergilendirme kapsamına alınmamış olan kişi ya da konularla ilgili vergi istisnası ya da muafiyetinden bahsedilebilmesi mümkün değildir. Ücret ödemeleri, Gelir Vergisi Kanunu'nun 61'inci maddesindeki genel tanım nedeniyle vergilendirme konusudur. Herhangi bir ücret ödemesinin vergi dışında tutulması isteniyor ise bunun kanunla muafiyet, istisna ya da indirim olarak düzenlenmesi şarttır.

Türkiye'de vergi harcamaları konusunda çok az sayıda nitelikli çalışma yapıldığı ve bu çalışmaların da vergi harcamaları boyutunun çok az bir kısmını kapsadığ görülmektedir (Yılmaz, 2007: 145). Onuncu Kalkınma Planı'nda (2014-2018) “Kamu Gelirlerinin Kalitesinin Artırılması Programı"nın birinci bileşeni olarak; istisna, muafiyet ve indirimler nedeniyle oluşan vergi harcamalarının mali etkilerinin tahmin edilmesi ve vergi harcamaları konusunda kamuoyunun düzenli ve ayrıntılı bilgilendirilmesi hususlarına yer verilmiştir $^{8}$. Bu itibarla, ücretlere yönelik vergi harcamalarının tamamının vergi harcamaları listesinde yer alması, bunların mali etkilerinin tahmin edilmesi, vergi harcaması hesap ve tahminlerine yansıması ve bu hususta kamuoyunun düzenli ve ayrıntılı bilgilendirilmesi gerekmektedir.

Onuncu Kalkınma Planı Vergi Özel ihtisas Komisyonu Rapor'unda; "Vergi harcamalarının mali boyutuna yönelik Merkezi Yönetim Bütçe Kanunlarında yer alan tahminler bu alandaki eksikliğin giderilmesi için çok önemli bir adım oluşturmakla birlikte, yayımlanan vergi harcaması tahminlerinin bütün vergi harcamalarını kapsamadığ görülmektedir. Vergi harcaması olarak değerlendirilen tüm indirim, istisna, muafiyet ve teşviklerin mali boyutunun tespit edilerek raporlanması daha sağlıklı politikalar üretilmesi için son derece önemli görülmektedir.” denilmek suretiyle mevcut listenin eksik olduğu

8 Uzun Vadeli Strateji ve Sekizinci Kalkınma Planı 'nda (2001-2005) beş yıllık kalkınma planının makroekonomik politikalarl, hedefleri, tahminleri bölümünde "İstisna, muafiyet ve vergi indirimi gibi vergi harcamalart ekonomik ve sosyal politikalar çerçevesinde yeniden düzenlenecek, vergi harcamalarl yoluyla alınmasından vazgeçilen tutarlar bütçe kanunu kapsamında ayrıntılı bir şekilde raporlanacaktır. " ifadesine yer verilmiştir. 
hususu ifade edilmiş, yine aynı raporda vergi harcamalarının günün ihtiyaçlarına ve değişen ekonomik şartlara göre gözden geçirilmesi gereğine işaret edilmiştir9. Bu tespit ve önerilere paralel olarak, ücretlere iliş̧in indirim, istisna ve muafiyetlerden vergi harcaması niteliğinde olanların tamamının vergi harcamaları listesinde yer alması gerekir. Ayrıca, Orta Vadeli Program'da (2015-2017) yer alan "Vergi harcamalarının gözden geçirilmesi ve bu alanda kamuoyunun düzenli ve ayrıntılı olarak bilgilendirilmesi çalışmalarına hız verilecektir." ile Orta Vadeli Mali Plan'da (2016-2018) yer alan "Kamu gelirlerinin kalitesinin artırılmas1 kapsamında istisna, muafiyet ve indirimler nedeniyle oluşan vergi harcamalarının mali etkilerinin analiz edilmesi, sonuca göre gerekli düzenlemelerin yapılması ve vergi harcamaları konusunda kamuoyunun sürekli olarak bilgilendirilmesi çalışmaları sürdürülecektir." ifadelerinden ücret gelirlerine ilişkin vergi harcamalarının da doğru bir şekilde hesaplanması ve bu konuda kamuoyunun sağlıklı bir şekilde bilgilendirilmesi yönünde adımlar atılması gerektiği sonucuna ulaşmak mümkündür.

Esasen mevzuatta ücret gelirlerine yönelik vergi istisna, muafiyet ya da indirimi olarak karşımıza çıkan ve standart vergi yapısının bir unsuru olarak nitelendirilmesi mümkün olmayan birçok kanun hükmü vergi harcamaları listesinde yer bulamamaktadır. Hangi muafiyet ve istisna hükmünün vergi harcaması hangilerinin standart vergi uygulaması sayılacağı konusunda duraksama ve tereddütler bulunmaktadır. Bütçe kanunları ekinde yer alan vergi harcamaları listesinde; "vergi türleri itibariyle vergi harcaması tahminleri" yer almasına karşılık "ücretlere ilişkin vergi harcaması" bazında belirlenen tutarların kamuoyu ile paylaşılmadığı görülmektedir. Yürürlükte olmayan bazı ücret unsurları ile ilgili istisna hükmü vergi harcamaları listesinde yer alırken damga vergisi ile sosyal güvenlik katk1 payları istisnalarının bu listede yer almadığı görülmektedir.

Ücretlere yönelik getirilen bazı muafiyet ve istisnaların vergi harcamaları listesinde yer almaması önemli bir eksikliktir. Bu durum doğal olarak vergi harcaması listesinde yer alan gelecek yıllara ilişkin vergi türleri itibariyle toplam vergi harcaması tahminlerine de yansımaktadır. Bilhassa, bütçenin disiplin altına alınması gayretleri, devletin vazgeçtiği vergi tutarının bilinmesini zorunlu kılmaktadır. Bu tutarın, gelir unsurları

9 Benzer şekilde, Dokuzuncu Kalkınma Planı Vergi Özel İhtisas Komisyonu Raporu'nda, "Vergi politikalarının ve vergiye yönelik düzenlemelerin maliyet etkisinin analizinde, vergi istatistiklerinin mevcudiyeti oldukça önemlidir. Özellikle, vergi harcamaları ve sektörel vergi istatistiklerine ait verilerin olmaması, vergi politikaları ve uygulamalarının analizini güçleştirmektedir... Mükelleflerin vergiye bakış açısının değisştirilmesi ve toplanan vergilerin iyi kullanıldığına inandırılması gerekir. Toplumda vergi bilincinin yerleştirilmesi ve mükelleflerin vergiye bakış açısının değiş̧tirilmesi, toplanan vergilerin topluma kamu hizmeti olarak döneceği hususunda yeterli güven ve inancın sağlanması şartına bağlıdır. Bu bağlamda kamu harcamalarında şeffaflık, yolsuzlukla mücadele konusundaki kararlıllk öncelikli amaçlardan olmalıdır. Şeffaflık ve saydamlık ilkelerinin gereği olarak ve toplumun bilgilendirilmesi amactyla vergi istatistikleri, vergi harcamalart gibi kalemleri de içerecek şekilde daha ayrıntılı ve düzenli bir takvimle yayınlanmalıdır. "şeklinde tespit ve önerilere yer verilmişstir. 
Öztürk, İ. (2016), "Bütçe Kanununa Ekli Vergi Harcamaları Listesinin Mevzuatla Ücret Gelirlerine İlişkin Getirilen Muafiyet, İstisna ve İndirimler Bağlamında Analizi”, Sosyoekonomi, Vol. 24(27), 57-83.

itibarıyla ayrı ayrı tespit edilmesi, bir başka ifade ile ücret gelirlerine yönelik vergi harcamalarının ayrı bir kalem olarak hesap ve tahmini, devlet için olduğu kadar mali şeffaflık bağlamında kamuoyu açısından da önemlidir. Ücretlere ilişkin vergi harcamaları tutarının olabildiğince net bir şekilde bilinmesi, bu tutarın bütçe üzerindeki mali etkisinin tam olarak irdelenebilmesini, gerektiğinde bu konuda fayda-maliyet analizi yapılabilmesini, dolayısıyla daha sağlıklı politikalar üretilebilmesini mümkün kılacaktır.

\subsection{Vergi Harcamaları Listesinde Yer Almayan Muafiyet ve İstisnalar}

Vergi harcaması listesinde ücret gelirlerine ilişkin olarak yer alan muafiyet, istisna ve indirimlerin ağırlıklı olarak Gelir Vergisi Kanunu ile sınırlı olduğu görülmektedir. $\mathrm{Bu}$ çalışmada, 2015 yılı Bütçe Kanunu ekinde yer alan vergi harcama listesi dikkate alınmıştır. "Vergi harcama listesi” ifadesinden aksi belirtilmediği müddetçe 2015 yılı Bütçe Kanunu ekinde yer alan vergi harcama listesinin anlaşılması gerekir. Henüz kanunlaşmamış olmakla birlikte 2016 yılı Bütçe Kanunu tasarısı ekinde yer alan vergi harcamaları listesi de, ücret gelirlerine ilişkin olarak, 2015 yılı Bütçe Kanunu ekinde yer alan vergi harcamaları listesinin aynıdır. Oysaki yürürlükteki kanun hükümlerinin tetkiki neticesinde, ücretlere yönelik muafiyet, istisna ya da indirim düzenleyen ancak vergi harcamaları listesinde yer almayan 40 ayrı kanunda yer alan muhtelif hükümler tespit edilmiş ve söz konusu kanun hükümleri çalışma ekinde "Vergi Harcamaları Listesinde Yer Almayan Ücret Gelirlerine Yönelik Muafiyet ve Istisnaların Kanuni Dayanakları” başlıklı Tablo 1'de belirtilmiştir. Bu hükümlerin büyük bir çoğunluğu kamu personel ücretlerine yönelik vergi muafiyet ve istisnası niteliği taşımakta olup hiç birisine bütçe kanunu ekindeki vergi harcama listesinde yer verilmemiştir. Bu muafiyet ve istisnaların standart vergi uygulaması (benchmark) ya da genel kabul görmüş bir vergi yapısı unsuru olarak nitelendirilmesi, aşağıda açıklanacağı üzere mümkün değildir. Bir başka ifade ile vergi harcama listesinde vergi harcaması olarak yer alan muafiyet ve istisna hükümleri ile karşılaştırmalı olarak incelendiğinde, Tablo:1'deki muafiyet ve istisnaların tamamı vergi harcaması niteliğinde olup vergi harcamaları listesinde yer alması gereken unsurlardır.

Vergi harcamaları listesi ile Gelir Vergisi Kanunu'nun 24/4 maddesinde yer alan Devlet Memurları Kanunu'na göre ödenen yakacak yardımı vergi harcaması olarak kabul edilirken, 657 sayılı Devlet Memurları Kanunu uyarınca; yurt dışında görevlendirilenlere yapılan ödemeler (657 sayılı Kanun, md.78), kadrosu kaldırılan memurlara yapılan ödemeler (657 sayılı Kanun, md.91), tazminatlar (657 sayılı Kanun, md.152), fark aylıklar (657 sayılı Kanun, md.156), aile yardımı (657 sayılı Kanun, md.203), ölüm yardımı (657 sayılı Kanun, md.208), makam tazminatı (657 sayılı Kanun, ek md.26), öğretim yılına hazırlık ödeneği (657 sayılı Kanun, ek md.32), nöbet ücreti (657 sayılı Kanun, ek md.33) ve sınıf değiştirme tazminatı (657 sayılı Kanun, geçici md.39) gibi benzer nitelikte birçok ödemenin vergiden istisna tutulmuş olmasının vergi harcaması olarak kabul edilmemesinin makul bir izahı bulunmamaktadır. 657 sayılı Kanun uyarınca ödenen yakacak yardımına yönelik istisna hükmü vergi harcaması olarak kabul edilerek vergi harcamaları listesinde yer verilirken aynı 
Kanun uyarınca yapılan bazı ödemelere tanınan istisna hükmünün vergi harcaması olarak nitelendirilmemesi ve vergi harcamaları listesinde yer almaması açık bir çelişkidir.

Gelir Vergisi Kanunu'nun 61'inci maddesi uyarınca, her ne ad altında olursa olsun hizmet erbabına, hizmet karşılığı ödenen tüm tutarlar ücret tarifi kapsamına girer ve ücret olarak vergilendirilir. Asgari ücretin bile vergilendirildiği bir vergi sisteminde kamu personeline yapılan bazı ücret ödemelerinin vergiden bağışık tutulması durumunu; standart vergi uygulaması, standart vergi yapısının bir unsuru olarak kabul etmek mümkün değildir. Vergi harcaması niteliği açık olan bu istisnaların vergi harcamaları listesinde yer almamış olması önemli bir eksikliktir.

Vergi harcamaları listesindeki, vergi harcama tahminlerini gösteren tabloda; vergi harcaması kavramının en genel anlamda devletlerin gelir toplamını azaltan, standart vergi sisteminden ayrılan ayrıcalıklar veya istisna ve muafiyetler olarak tanımlanabileceği belirtilmiş, bu bağlamda bazı indirim, istisna ve muafiyetlerin standart vergi sisteminin unsurları olmaları nedeniyle vergi harcaması kapsamı dışında tutulabildiği ifade edilmiştir. Ancak, kamu personel ücretlerine ilişkin muafiyet ve istisnaların vergi harcama listesinde yer almamasını, bunların "standart vergi sisteminin unsuru" oldukları gerekçesine dayandırmak mümkün değildir. Söz konusu listede, "köy muhtarlarının köy bütçesinden ödenen ücretlerinin gelir vergisinden istisna edilmesi” (Gelir Vergisi Kanunu, md.23/5) hükmü vergi harcaması olarak yer alırken, "köy muhtarlarına verilen aylık ödeneğin damga vergisi hariç herhangi bir vergi ve kesintiye tabi tutulamayacă̆ " (2108 sayılı Muhtar Ödenek ve Sosyal Güvenlik Yasası, md.1) hükmüne yer verilmemiş olmasını "standart vergi sisteminin unsuru" olma gerekçesine dayandırmak mümkün değildir. Bir başka ifade ile köy muhtarına yapılan ücret ödemesine ilişkin istisna standart vergi harcaması sayılmayıp vergi harcamaları listesinde yer alırken bir başka kanun ile köy muhtarlarına verilen aylık ödeneğe tanınan istisnanın vergi harcaması olarak dikkate alınmaması çelişki arz etmektedir.

Gelir Vergisi Kanunu'nun 29/2 maddesinde yer alan uçuş ve dalış gibi hizmetlere tanınan istisna, vergi harcamaları listesinde yer almıştır. Buna rağmen, 2629 sayılı Uçuş, Paraşüt, Denizaltı, Dalgıç ve Kurbağa Adam Hizmetleri Tazminat Kanunu'nun 17'inci maddesindeki ve 3160 sayılı Emniyet Teşkilatı Uçuş ve Dalış Hizmetleri Tazminat Kanunu'nun 6'ncı maddesindeki uçuş ve dalış hizmetleri istisnasının bu kapsamda vergi harcaması olarak vergi harcamaları listesinde yer almaması bir başka çelişki örneğidir.

Yardım sandıkları tarafından yapılan ölüm yardımlarına tanınan istisna (Gelir Vergisi Kanunu, md.25/9) vergi harcaması listesinde yer alırken, 657 sayılı Devlet Memurları Kanunu'nun 208'inci maddesi uyarınca ölüm yardımı ödeneğine tanınan istisna ile 926 sayılı Türk Silahlı Kuvvetleri Personel Kanunu'nun 177'nci maddesi kapsamında yapılan ölüm yardımı ödeneğine tanınan istisnaya yer verilmemiş olması tereddüt doğurmaktadır. 
Öztürk, İ. (2016), "Bütçe Kanununa Ekli Vergi Harcamaları Listesinin Mevzuatla Ücret Gelirlerine İlişkin Getirilen Muafiyet, İstisna ve İndirimler Bağlamında Analizi”, Sosyoekonomi, Vol. 24(27), 57-83.

500 sayılı Kıbrıs'a Gönderilecek Türk Askeri Birliği Mensuplarının Aylık ve Ücretleriyle Çeşitli İstihkakları ve Birliğin Başka Giderleri Hakkında Kanun'un 1'inci maddesi uyarınca Kuzey Kıbrıs Türk Cumhuriyeti'nde bulunan Türk Askeri Birlikleri personeli ile genel ve katma bütçeli daire ve idareler, kamu iktisadi kurumları ve döner sermayeli kuruluşlar personeline bir ayda aldıkları aylık (ek gösterge dâhil), taban aylığı, kıdem aylığı, ödenek ve her türlü zam ve tazminat toplamının net tutarının \%100'ünü geçmemek üzere Bakanlar Kurulunca tespit edilecek tutara tanınan vergi istisnasının "standart vergi uygulaması" kabul edilerek vergi harcama listesinde yer almaması hukuken muteber bir gerekçeye dayanmamaktadır. Aynı şekilde 5176 sayılı Kamu Görevlileri Etik Kurulu Kurulması ve Bazı Kanunlarda Değişiklik Yapılması Hakkında Kanun'un 2'nci maddesi uyarınca Kurul Başkan ve üyelerine, fiilen görev yapılan her gün için 3000 gösterge rakamının memur aylık katsayısı ile çarpımı sonucu bulunacak miktardaki huzur hakkı ödemesine tanınan istisna hükmünü de standart vergi sisteminin bir unsuru olarak görmek mümkün değildir. 6216 sayılı Anayasa Mahkemesinin Kuruluşu ve Yargılama Usulleri Hakkında Kanun'un 31'inci maddesinde yer alan, geçici olarak Anayasa Mahkemesi'nde görevlendirilenlere ödenecek maaş farklarının vergiye tabi tutulmayacağı hükmü de standart vergi sisteminin bir unsuru sayılamaz.

Gelir Vergisi Kanunu'nun 23/3 maddesinde yer alan “Toprak altı işletmesi halinde bulunan madenlerde cevher istihsali ve bununla ilgili diğer bütün işlerde çalışanların münhasıran yer altında çalıştıları zamanlara ait ücretler" için getirilen istisna hükmü standart vergi uygulaması olarak nitelendirilmemiş, vergi harcaması olarak kabul edilerek vergi harcamaları listesinde yer almışken, 6087 sayılı Hâkimler ve Savcılar Yüksek Kurulu Kanunu'nun 34'üncü maddesi mucibince Hâkimler ve Savcılar Yüksek Kurulu üyelerine, 30.000 gösterge rakamının memur aylıklarına uygulanan katsayı ile çarpımı sonucu bulunacak miktarda aylık ek tazminat ödemesini vergiden bağışık tutan düzenlemeyi vergi harcaması olarak kabul etmemenin izahı güçtür. Madenlerde ve münhasıran yer altında çalışılan zamana ilişkin ücretlere tanınan istisna, genel kabul görmüş bir vergi yapısından ayrılma olarak nitelendirilirken, yabancı dil tazminatı (375 sayılı KHK, md.2), makam tazminatı (926 sayılı Kanun, ek md.18), fazla çalışma ücreti (3201 sayılı Kanun, ek md.21), sıkıyönetim hizmet zammı (1402 sayılı Kanun, md.26) gibi ödemelere tanınan istisnanın genel kabul görmüş vergi yapısından ayrılma olarak nitelendirilmemesi ve vergi harcaması olarak kabul edilmemesi dikkat çekicidir.

Tablo 1'deki tüm istisna ve muafiyet hükümleri için benzer yorumu yapmak ve bu örneklerin sayısını artırmak mümkündür. Tablo 1'de yer alan muafiyet ve istisnalar, kanun ile düzenlenmemiş olsalardı söz konusu ücret ödemeleri vergi konusuna girecek ve ücret olarak vergilendirilecektir. Bunların vergi dışı tutulması ancak kanun ile getirilen muafiyet ve istisnalar sayesinde mümkün olmuştur. Bu muafiyet ve istisna hükümleri vergi harcamaları listesinde yer alan muafiyet ve istisna hükümleri ile karşılaştırıldığında, vergi harcamaları listesinde yer almamalarını haklı kılan bir gerekçe bulunmamaktadır. Ayrıca, Tablo 1'de belirtilen Türk Uluslararası Gemi Sicili Kanunu, İşsizlik Sigortası Kanunu ve Özel Öğretim Kurumları Kanunu ile özel sektör çalışanlarına yönelik olarak getirilen vergi 
muafiyet ve istisnalarına da vergi harcama listesinde yer verilmemesine ilişkin olarak da benzer yorumu yapmak mümkündür.

Şunu da belirtmek gerekir ki ücretlere yönelik söz konusu muafiyet ve istisna düzenlemelerinin sayısı ile bu kapsama giren kurum ve personel çeşitliliği nedeniyle ortaya çıkan dağınık yapı, ücret gelirlerine ilişkin vergi harcamalarının vergi gelirlerindeki azaltıcı etkisinin hesaplanmasını güçleştirmektedir. Bu güçlüğe rağmen Tablo 1'de yer alan ve çoğu kamu personel ücretlerine yönelik olan muafiyet ve istisnaların anayasal ücret adaletinin ${ }^{10}$ tesisi açısından vergi harcaması kapsamında analize konu edilmeleri yararlı olacaktır. Kamu personelinin ve özel sektör çalışanlarının farklı vergisel kurallara bağlı kılınması anayasal eşitlik ilkesine aykırı değildir. ${ }^{11}$ Ancak, kamu kesimi ile özel kesim çalışanları arasında hatta kamu çalışanlarının kendi içinde aşırı vergi yükü farkının oluşması halinde; Anayasa'nın 55'inci maddesinin gerekçesinde belirtilen kamu kesiminde çalışanlar ile özel kesimde çalışanlar arasında; ister işçi ister memur olsun ücret, aylık, ikramiye ve sosyal yardımlar bakımından hakkaniyet ve dengenin sağlanması esası zedelenebilecektir. Bu itibarla, vergi harcaması niteliğindeki tüm muafiyet ve indirimlerin vergi harcaması listesinde yer alması, vergi harcaması hesap ve tahminlerinde dikkate alınması, mali ve sosyal etkilerinin analizi birçok açıdan önem taşımaktadır.

\section{2. Ücretlere İlişkin Standart Vergi Uygulaması Üzerinde Mutabakat Bulunmaması}

Tüm vergi ayrıcalıkları vergi harcaması olarak nitelendirilemez. Çünkü bazı vergi ayrıcalıkları vergi sisteminin yapısal özellikleri olarak düşünülür. Bundan dolayı da vergi yapısını oluşturan standartlarla birleştirilmişlerdir. Bir vergi ayrıcalığını, vergi harcaması olarak nitelendirebilmek için bu ayrıcalığın kamu harcamasının bir alternatifi olması

10 Yasa koyucu vergilendirme yetkisini kullanırken, anayasal kurallara uymak ve vergi yükünün adalete uygun ve sosyal amaçlı dağıtımını sağlamak koşuluyla, gelir, servet veya harcamanın vergilendirilmesinde konulara, nitelik veya miktarlara göre kimi değişik ölçütler getirebilir, gelirin unsurlarına ve miktarına göre ayrı yükümlülükler ve oranlar belirleyebilir. Ücret gelirlerinin diğer gelir unsurlarına göre salt emeğe dayalı olarak elde edilen gelir niteliğinde olması ve vergi baskısının yüksekliği nedeniyle özellikle bu geliri elde edenlerin ekonomik durumları ile vergi oranları arasında doğrudan bir bağlantının kurulmaması ve ücretlilerden vergi alınırken mali gücün gözardı edilmesi düşünülemez. Anayasa'nın 55 ’inci maddesinde ücretin emeğin karşılığl olduğu, Devletin çalışanların yaptıkları işe uygun adaletli bir ücret elde etmeleri ve diğer sosyal yardımlardan yararlanmalarl için gerekli tedbirleri alacă̆ belirtilmiştir. Anayasa, ücreti, diğer gelirlerden farklı olarak özel şekilde düzenlemiş, bu düzenlemede ücretin özellikli ve ayrlk durumunu gözeterek, Devlet'e "adaletli bir ücret", için tedbir alma görevi vermek suretiyle koruma altına almıştır (Anayasa Mahkemesi 'nin 08.01.2010 tarih ve 27456 sayll Resmi Gazete'de yayımlanan 15.10.2009 tarih ve E.2006/95, K.2009/114 sayll kararl).

11 Anayasa Mahkemesi'nin 9/4/2015 tarih ve 29321 sayll Resmi Gazete'de yaylmlanan 11/9/2014 tarih ve E.2014/52, K.2014/139 sayll kararl. 
gerekmektedir (Erdem vd., 2013: 97-98). Vergi harcamaları kavramının tanımı konusunda belli ölçüde mutabakat sağlanmış olmakla birlikte, ${ }^{12}$ hangi vergi indirim, istisna ve muafiyet kalemlerinin vergi harcaması kapsamına alınması gerektiğine dair farklı uygulamalar bulunmaktadır. Vergi harcamalarına ilişkin çalışmalarda standart vergi uygulamaları, uluslararası literatürde "benchmark" olarak adlandırılır. Vergi sistemi üzerindeki imtiyaz unsurlarının bazıları, savunma ve askeri amaçlı vergi istisnalarında olduğu gibi vergi sisteminin yapısal unsurları olarak görülmekte ve vergi harcaması değil standart vergi uygulamaları olarak kabul edilmektedir. Bazı ülkelerde, vergi harcamasının tanımı yapılmış olmakla birlikte, konu ile ilgili kanun hükümlerinin standart vergi uygulamaları mı olduğu yoksa vergi harcaması kapsamında mı değerlendirilmesi gerektiği konusunda sınıflandırmada zorluklarla karşılaşılmaktadır (Maliye Bakanlığı Gelir Politikaları Genel Müdürlüğü, 2007: 4-8). Yapılan çalışmaların sayı ve nitelik olarak yeterli düzeye ulaşmamasının da etkisiyle, uygulamada hangi vergi istisna, muafiyet ve indirimlerinin vergi harcaması olarak değerlendirileceği ve vergi harcaması tutarının hesaplamasında dikkate alınacağı konusunda fikir birliği oluşmamıştır.

Mevzuatta, vergi harcamalarına oldukça benzerlik göstermekle beraber, standart vergi uygulaması olarak düşünülmesi sebebiyle vergi harcamaları listesinde yer almayan birçok örnek bulunmaktadır. Ücret gelirlerine ilişkin olarak mevzuatımızda yer alan bir takım indirim, muafiyet ve istisna düzenlemesinin vergi harcaması tanımına benzer bir içerik taşımasına rağmen bunların standart vergi uygulaması olarak kabul edilmesi sebebiyle vergi harcamaları listesinde yer almadığı görülmektedir. Bu liste dışı bırakmanın her durumda geçerli bir "standart vergi uygulaması" tanım ve kriterine dayandırıldığını söylemek kanaatimizce bir hayli güçtür.

Gelir Vergisi Kanunu'nun 15'inci maddesindeki “Diplomat Muaflığg”" ve 16'nc1 maddesindeki “Ücret İstisnası"nın vergi harcamaları listesinde yer almamasını standart vergi uygulaması olarak kabul edildikleri varsayımı ile açıklamak mümkündür. Bilhassa karşılıklı

Ülkelerde farkl endüstrilere, vergileme konusunda ayrı uygulama yapılması için güçlü nedenler olabilir. Bu özel uygulamalar bazen vergi oranlarında kü̧̈ük değişiklikler şseklinde ortaya çıkabilir. Bu vergi avantajları, farkllliklarl ve indirimleri vergi harcamaları olarak adlandirlabilir (Stiglitz, 1986: 516-517). Vergi harcamasl, vergi konulması ve uygulaması için gerekli temel bir düzenleme olmayan, bazı mükellef gruplarının yükünü azaltmak, teşvik etmek, yönetimi kolaylaştırmak ve benzeri nedenlerle tanınan; muafiyet, istisna ve indirimlerin yol açtığı kaybı ifade etmektedir (Akdoğan, 2007: 173). Vergi harcamalarl, vergi matrahının veya verginin azalmasina yol açmak suretiyle devletin bütçe gelirleri açısından her türlü kaybina sebep olan vergisel düzenlemelerdir (Bratic, 2006: 115). Surrey tarafindan yapılan vergi harcamasinın tanımı normatif vergi yapısın dikkate almaktadır. Bu tanımlamada vergi yükümlülüğ̈̈nü azaltan uygulamalar vergi sistemince belirlenmis yapıdan, yani normatif vergi yapısindan ayrllma olarak nitelendirilmektedir. Bir vergi sisteminin normatif yapısından ayrılan, sapma gösteren unsurlar vergi istisnalarl, vergi muafiyetleri, indirimler, mahsuplar, oran indirimleri ve vergi ertelemesi gibi vergi yükümlüsüne avantaj sağlayan unsurlardır (Ferhatoğlu, 2005: 81, 83). 
Öztürk, İ. (2016), "Bütçe Kanununa Ekli Vergi Harcamaları Listesinin Mevzuatla Ücret Gelirlerine İlişkin Getirilen Muafiyet, İstisna ve İndirimler Bağlamında Analizi”, Sosyoekonomi, Vol. 24(27), 57-83.

olmak şartı da dikkate alınarak, birçok ülkenin vergi sisteminde yer alan bu düzenleme genel kabul görmüş bir vergi yapısından ayrılma olarak nitelendirilmemiştir. Gelir Vergisi Kanunu'nun; "Müteferrik İstisnalar"' düzenleyen Altıncı Bölümünün 25'inci maddesinin 3, $4,5,6,7,9$ ve 10 'uncu bentleri, vergi harcamaları listesi incelendiğinde görüleceği üzere, vergi harcamaları arasında sayılırken aynı maddenin 1'inci bendinde yer alan "ölüm, sakatlık, hastalık ve işsizlik sebepleriyle (işe başlatmama tazminatı dâhil) verilen tazminat ve yapılan yardımlar", 2 'nci bendinde yer alan "muhtaç olanlara belli bir süre için veya hayat kaydıyla yapılan yardımlar" ve 8'inci bendinde yer alan "genel olarak nafakalar (alanlar için)" konularındaki düzenlemelerin vergi harcaması olarak nitelendirilmediği ve vergi harcamaları listesinde yer almadığı görülmektedir. Benzer şekilde; Gelir Vergisi Kanunu'nun vatan hizmetleri yardımlarını düzenleyen 26'ncı maddesinin, teçhizat ve tayın bedellerini düzenleyen 27 'nci maddesinin, tahsil ve tatbikat ödemelerini düzenleyen 28 'inci maddesinin, engellilik indirimini düzenleyen 31 'inci maddesinin, asgarî geçim indirimini düzenleyen 32'nci maddesinin vergi harcaması olarak takdir edilmediği görülmektedir. Anılan düzenlemelerin, "standart vergi uygulamaları (benchmark)" olarak değerlendirildiği anlaşılmaktadır.

Vergi Harcamaları Raporunda; vergi kanunlarında yer alan hükümlerin vergi harcaması mı yoksa benchmark mı olduğunun ayrımını yapmanın oldukça yoğun ve kapsamlı çalışmalar gerektiren bir süreç olduğu, bazı hükümlerin vergi harcaması ile benchmark arasındaki ince çizgi üzerinde bulunduğu, ancak bazı hükümlerin vergi harcaması veya benchmark olarak tasnifinde kesin bir ayrıma gidilebildiği belirtilerek, Gelir Vergisi Kanunu'nun 25'inci maddesi ile "ölüm, engellilik, hastalık ve işsizlik sebepleriyle verilen tazminat ve yapılan yardımlar" 1 gelir vergisinden müstesna tutulması "kesin bir ayrımla" benchmark olarak tasnif edilebilecek hükümlere örnek olarak gösterilmiştir. Ayrıca, bu hükümde yer alan tazminat ve yardımların bir gelir unsuru olarak kabul edilemeyeceği, bu tazminat ve yardımların mükellefin bir zararının karşılanması olarak değerlendirilmesi gerektiği, dolayısıyla anılan hüküm çerçevesinde elde edilen menfaatlerin vergilendirilmemesi gerektiğinden bu uygulamanın bir benchmark olduğu ifade edilmiştir. Belirtilen "kesin" tespite rağmen, Gelir Vergisi Kanunu'nun 25/9 maddesinde yer alan; yardım sandıkları tarafından ölüm, engellilik, hastalık, doğum, evlenme gibi sebeplerle üyelerine yapılan yardımlar vergi harcaması olarak kabul edilmiş ve vergi harcamaları listesine dâhil edilmiştir. Kesin bir ayrımla (benchmark) standart vergi uygulaması olarak nitelenen bir istisna tam aksine vergi harcaması olarak yani standart vergi uygulamasından sapma olarak kabul edilmiştir.

Hangi düzenlemelerin vergi harcaması olduğu, hangilerinin benchmark olduğu konusunda vergi harcamaları listesindeki çelişkili durumlara ilişkin verilebilecek çarpıcı bir örnek, Gelir Vergisi Kanunu'nda düzenlenmiş bulunan aidatlara tanınan indirim hakkına ilişkindir. Kanun'un 40/8 maddesindeki "İşverenlerce, Sendikalar Kanunu hükümlerine göre sendikalara ödenen aidatlar safi kazancın tespitinde gider olarak indirilebilir. " hükmü vergi harcamaları listesinde yer almamaktayken, 63/4 maddesindeki "Çalışanlar tarafindan ilgili kanunlarına göre sendikalara ödenen aidatların indirim konusu yapılabileceği”" 
hükmü, vergi harcamaları listesinde yer almaktadır. Bu durum sosyal hayatın gerçeklerine aykırı şekilde; ticari kazançların ele alındığı 40'ıncı maddede yer alan sendikalara yapılan “aidat ödemesi”nin standart vergi uygulaması olarak algılandığı, buna karşılık ücretlerin ele alındığı 63'üncü maddesindeki sendikalara yapılan “aidat ödemesi"nin vergi harcaması olarak telakki edildiği sonucunu ortaya çıkarmaktadır (Öztürk\&Sabuncu, 2012: 68-69). Bir başka ifade ile işverenlerce sendikalara ödenen aidata tanınan indirim standart vergi uygulaması olarak kabul edilmiş ve vergi harcamaları listesinde yer almamış, buna karşılık çalışanlar tarafından sendikalara ödenen aidatların indirim konusu yapılması ise vergi harcaması olarak nitelendirilerek vergi harcamaları listesinde yer almıştır.

\subsection{Negatif Vergi Harcamalarının Dikkate Alınmamış Olması}

Negatif vergi harcaması uygulamasında da standart vergi sisteminden sapma söz konusudur. Ancak, burada bahse konu sapmaların, bazı vergilerde, belirlenen mal ve hizmetlerin genel tarifenin dışında ve diğer mal ve hizmetlere kıyasla daha yüksek oranda vergilendirilmesi şeklinde karşımıza çıktığı görülmektedir. Dolayısıyla burada, vergi harcamalarındaki istisna, muafiyet, indirim gibi mükelleflerin lehine sonuçlar doğuran ve devlet için bir gelir kaybı niteliği taşıyan uygulamaların tersine, katma değer vergisi ve özel tüketim vergisinde özellikle lüks tüketime tabi bazı mal ve hizmetlerde olduğu gibi aşırı bir vergilendirmeden söz edilebilir (Pedük, 2005: 24).

Vergi harcamalarının, bütçe üzerindeki toplam etkisi hesaplanırken negatif vergi harcamalarının da hesaba katılması suretiyle daha doğru neticelere ulaşılabileceği söylenebilir. Belirtilen niteliği göz önünde bulundurulduğunda, vergi harcamalarının, ülke bütçeleri içerisindeki parasal büyüklüğü hesap edilirken negatif vergi harcamalarının da hesaba katılmasının yerinde olacağı düşünülmektedir. Zira vergi harcamalarında bütçede bir gelir kaybından söz edilebilirken, negatif vergi harcamalarında devlet açısından fazladan bir gelir kaynağı imkânından bahsedilebilir. Öte yandan, gerek vergi harcamalarının bütçedeki yeri konusunda çalışmaların tarihçesinin oldukça yeni olması gerekse hangi uygulamaların vergi harcaması olduğu üzerinde bile bir mutabakat bulunmadığı dikkate alındığında, negatif vergi harcamaları ile ilgili ciddi çalışmaların ortaya konularak bütçede yerini almasının zaman alacağı, en azından bunun kısa vadede gerçekleşmesinin kolay olmayacağı açıktır.

Vergi harcamaları hesap ve tahminlerinde ve vergi harcamaları listesinde, ücretlere yönelik negatif vergi harcamaları konusunda herhangi bir bilgi ve açıklama yer almamaktadır. Bundan sonraki çalışmalara dayanak teşkil etmesi, vergi harcama tahmin ve hesaplarının daha gerçekçi olarak ortaya konulabilmesi ve bu yolla uluslararası vergi harcamaları karşılaştırmalarının daha sağlıklı bir biçimde yapılabilmesi açısından ücret gelirlerine yönelik negatif vergi harcamalarının da vergi harcaması listesinde ve vergi harcaması hesap ve tahminlerinde dikkate alınmasında yarar görülmektedir. 


\subsection{Yürürlükte Olmayan Ücret Unsuruna İlişkin İstisna Hükmüne Yer Verilmesi}

Gelir Vergisi Kanunu'nun 24/4 maddesinde; “657 sayll Devlet Memurlarl Kanununa göre ödenen yakacak yardımı"nın gelir vergisinden istisna edildiği hükme bağlanmıştır. Ancak 657 sayılı Devlet Memurları Kanunu'nun "yakacak yardımı" başlıklı 213'üncü maddesi 27.6.1989 tarih ve 375 say1lı Kanun Hükmünde Kararname'nin 32/b maddesi ile 1 Temmuz 1989 tarihinden geçerli olmak üzere yürürlükten kaldırılmıştır. Bir başka ifade ile yürürlükte 657 sayılı Devlet Memurları Kanunu'na göre ödenen bir yakacak yardımı bulunmamaktadır.

Buna rağmen mülga kanun hükmüne istinaden 2015 yllı Bütçe Kanunu ile 2016 yılı Bütçe Kanun Tasarısı ekinde yer alan vergi harcamaları listesinde yakacak yardımına bir vergi harcaması türü olarak yer verilmiştir. Söz konusu yakacak yardımı, 1 Temmuz 1989 tarihinden itibaren geçerli olmadığı halde, yakacak yardımına ilişkin istisna hükmü örneğin 2012 yılı Bütçe Kanunu ekindeki vergi harcamaları cetvelinde yer almazken, 2015 yılı Bütçe Kanunu ile 2016 yılı Bütçe Kanunu tasarısı ekindeki vergi harcamaları listesinde yer alması dikkat çekicidir.

Vergi harcama listesinin kamuoyunu aydınlatma ve mali saydamlık ilkesine hizmet amaçları da dikkate alındığında, yürürlükte olmayan yakacak yardımına ilişkin istisna hükmünün vergi harcamaları listesinden çıkartılmasının, kamuoyunun düzenli ve ayrıntılı bilgilendirilmesi ve hesaplanan rakamlara güven açısından önem taşıdığ düşünülmektedir.

\section{5. Ücretlere İlişkin Damga Vergisi İstisnalarına Yer Verilmemesi}

488 sayll Damga Vergisi Kanunu'nun 1'inci maddesinde; bu Kanuna ekli (1) sayılı tabloda yazılı kâğgtların damga vergisine tabi olduğu, (1) sayılı tablonun IV/1-b bölümünde de; maaş, ücret, gündelik, huzur hakkl, aidat, ihtisas zammı, ikramiye, yemek ve mesken bedeli, harcırah, tazminat ve benzeri her ne adla olursa olsun hizmet karşılı̆̆ alınan paralar (avans olarak ödemeler dâhil) için verilen makbuzlar ile bu paraların nakden ödenmeyerek kişiler adına açılmış veya açılacak cari hesaplara nakledildiği veya emir ve havalelerine tediye olunduğu takdirde nakli veya tediyeyi temin eden kâğttlar üzerinden binde 7,59 oranında damga vergisi alınacağı hükme bağlanmıştır.

Bu hüküm uyarınca, hizmet karşıllğı olarak yapılan her türlü ödeme damga vergisine tabidir. Bir ücret unsurunu damga vergisi dışında tutulabilmesi için bu konuda kanun ile damga vergisi ayrıcalığının getirilmiş olması şarttır.

Tablo 1'de yer alan istisna ve muafiyet hükümlerinin bazıları, gelir vergisinin yanı sıra damga vergisini de kapsamaktadır. Örneğin; 657 sayılı Devlet Memurları 
Kanunu'nun 208'inci maddesi uyarınca ölüm yardımı ödeneği hiçbir vergi ve kesintiye tabi tutulmaksızın ödenir. Benzer şekilde, 926 sayılı Kanun'un 154'üncü maddesi uyarınca aile yardımı ödeneği de hiçbir vergi ve kesintiye tabi tutulmaksızın ödenir. Anılan düzenlemelerde açıkça "damga vergisi" ibaresi yer almamakla birlikte "hiçbir vergi"ye tabi tutulmayan ödemeler için damga vergisi kesintisinin de söz konusu olmayacağ tartışmasızdır. Öte yandan, Tablo 1'de yer alan bazı hükümlerde, belirtilen ücret ödemelerinin damga vergisine tabi olmadığ 1 açıkça belirtilmek suretiyle damga vergisi istisnası düzenlenmiştir. Örneğin 375 sayılı KHK'nin 28'inci maddesi kapsamında güvenlik kuvvetlerine ödenecek ek tazminatlar damga vergisi dâhil hiçbir vergi ve kesintiye tabi değildir.

Ücret ödemeleri sadece gelir vergisine konu teşkil etmezler. Ücret ödemeleri üzerinden damga vergisi kesintisi de söz konusudur. Bu itibarla ücretlere ilişkin vergi harcaması hesap ve tahminlerinde damga vergisi istisnalarının da dikkate alınması ve damga vergisi istisnalarına ilişkin hükümlerin de vergi harcamaları listesine dâhil edilmesi gerekmektedir. Oysaki vergi harcamaları listesinde vergi harcamalarının kanunî dayanaklarına yer verilirken, Damga Vergisi Kanunu'ndaki ya da başka kanunlardaki damga vergisi muafiyeti ya da istisnası içeren hükümlere yer verilmemiştir. Benzer olarak, vergi harcamaları listesindeki, vergi türleri itibariyle toplam vergi harcaması tahminleri tablosunda da Damga Vergisi Kanunu'na ilişkin bir tahmin ya da hesaplama bulunmamaktadır.

\subsection{Sosyal Güvenlik Katkı Paylarına İlişkin İstisnaların Dikkate Alınmaması}

Vergi, yükümlülerin gelirleri, servetleri veya harcamaları üzerinden alınır. Bireysel planda vergi yükü, vergi yükümlülerinin ödedikleri vergilerin gelirlerine oranını ifade eder. Millî ekonomi açısından vergi yükü, vergi ve vergiye benzer kamu gelirlerinin, gayrisafi millî hasılaya olan oranıdır. Vergi yükünün hesaplanması ile güdülen amaç vergi yükümlülerinin gelirlerinden ne kadarı üzerinde tasarruf yetkisi bulunmadığının saptanması olduğuna göre, sosyal sigorta keseneklerinin vergi yükü hesabı içine katılması gerekir (Türk, 2011: 214-215). Sosyal güvenlik primleri vergi yükü hesaplamalarına dâhil edildiğinde -ki bazı ülkelerde dâhil edilmektedir- sosyal güvenlik primleri için geçerli olan ayrıcalıklar vergi harcaması olarak da kabul edileceklerdir (Giray, 2002: 50).

Toplam vergi yükü karşılaştırmalarında parafiskal yükümlülüklerin hesaba katılıp katılmadığına bakmak gerekir. Aksi halde gelir grupları açısından farklı sonuçlara ulaşılabilir. Parafiskal yükümlülükler zorunludur. Bu tip yükümlülüklerin bir kısmı işçiler bir kısmının da işverenler tarafından ödeniyor olması vergi yükü hesaplamalarında çeşitli tartışmalara neden olmaktadır. Parafiskal yükümlülüklerin ödeme zorunluluğu olmakla birlikte, emekli olunduğunda eski ödemelerden fayda sağlanmaktadır. Yani ödeme yanında fayda da vardır (Korkmaz, 1998: 28). Bireyler tarafından devlete vergi ve vergi benzeri 
Öztürk, İ. (2016), "Bütçe Kanununa Ekli Vergi Harcamaları Listesinin Mevzuatla Ücret Gelirlerine İlişkin Getirilen Muafiyet, İstisna ve İndirimler Bağlamında Analizi”, Sosyoekonomi, Vol. 24(27), 57-83.

sosyal güvenlik primleri ödenmektedir. Sosyal güvenlik primlerinin ve kamu geliri niteliğindeki kurum aidatlarının vergiden farklı karakterleri olmakla birlikte, ödenmelerinin zorunlu olması ve bu kaynakların kamu denetiminde harcanması nedeniyle toplam vergi yükü hesaplamalarında dikkate alınırlar Öte yandan, sendika, dernek ve siyasî partiler ve kurumlarca oluşturulan sosyal yardım sandıkları için ödenen aidatlar vergi yükü hesaplamalarında dikkate alınmazlar. $\mathrm{Bu}$ tür ödemeler yasal zorunluluktan kaynaklanmamaktadır.

Toplam vergi yükü, sosyal güvenlik katkı payları dâhil veya hariç şekilde hesaplanabilir. $\mathrm{Bu}$ ödeme türlerinden hangilerinin vergi yükü hesaplamalarına dâhil edileceği ülkeden ülkeye değişiklik gösterebilmektedir. Bu nedenle vergi yükü ile ilgili uluslararası karşılaştırmalar yapılırken, vergi yükü hesabına dâhil edilen unsurların aynı ya da benzeşen unsurlar olup olmadığının dikkate alınması gerekir.

Sadece ülke için hesaplamalarda değil uluslararası karşılaştırmalar açısından da vergi yükü hesaplamaları sosyal güvenlik katkı payı dâhil ve hariç şeklinde yapılmaya başlanmıştır. Sosyal güvenlik primlerinin vergi ya da vergi benzeri malî yüküm olarak kabul edilmesine paralel olarak vergi harcamaları hesaplamalarında da sosyal güvenlik katkı payı istisnalarına yer verilmesi gerekecektir. Nitekim Tablo 1'de yer alan listedeki ücretlere yönelik bazı istisna hükümleri gelir vergisi ile damga vergisi yanında "sosyal güvenlik" kesintilerini de kapsamaktadır. Örneğin; 657 sayılı Kanun'un 208'inci maddesi uyarınca ölüm yardımı ödeneği hiçbir vergi ve kesintiye tabi tutulmaksızın ödenir. 926 sayılı Kanun'un 154'üncü maddesi uyarınca aile yardımı ödeneği subay ve astsubayların her ay aylıkları ile birlikte hiçbir vergi ve kesintiye tabi tutulmaksızın ödenir. 3466 sayılı Kanun'un 23 'üncü maddesi uyarınca uzman jandarma adaylarına okuldaki eğitim ve öğrenim süresince ödenecek harçlıklar hiçbir kesintiye ve vergiye tabi değildir. 5176 sayılı Kanun'un 2'nci maddesi uyarınca Kurul Başkan ve üyelerine, fiilen görev yapılan her gün için 3000 gösterge rakamının memur aylık katsayısı ile çarpımı sonucu bulunacak miktarda huzur hakkı ödenir, bu ödemeden damga vergisi hariç herhangi bir kesinti yapılmaz. 3201 sayılı Kanun'un ek 21 'inci maddesi uyarınca ödenen fazla çalışma ücretinden damga vergisi hariç herhangi bir vergi ve kesinti yapılamaz. Bu hükümler gereğince, ücret ödemesi yapılırken gelir vergisi, damga vergisi yanında sosyal güvenlik kesintisi yapılması da söz konusu değildir.

Vergi harcamaları listesinde, sosyal güvenlik primlerine ilişkin istisna kapsamına alınan kalemlere yer verilmediği görülmektedir. Ücretlere ilişkin gelir ve damga vergisi muafiyet ve istisnalarının yanı sıra sosyal güvenlik kesintisine ilişkin bağışıklıkların da dikkate alınması bilhassa vergi yükü karşılaştırmalarında olduğu gibi ülkeler arası vergi harcaması karşılaştııılmalarının da daha sağlıklı yapılmasına imkân tanıyacaktır. Sosyal güvenlik primlerinin vergi yükü hesaplamalarında kullanılmasının daha da yaygınlaşmasına paralel olarak sosyal güvenlik primlerine tanınan istisnaların da vergi harcaması hesap ve tahminlerinde kullanımının artması beklenmektedir. Bu itibarla, Maliye Bakanlığı ile Çalışma ve Sosyal Güvenlik Bakanlığı arasında gerekli koordinasyonun sağlanarak konuya 
ilişkin bilgi alışverişi ve veri tabanı oluşturulmasına yönelik çalışmaların başlatılmasında yarar vardir.

\section{Sonuç}

Vergi harcamaları devletin vazgeçtiği vergi gelirleridir. Diğer gelir unsurlarına yönelik olduğu gibi ücret gelirlerine ilişkin de vergi harcamaları bulunmaktadır. Bunlar daha çok vergi muafiyet ve istisnaları şeklinde düzenlenmiştir.

Standart vergi uygulaması olarak nitelendirilemeyecek olmasına rağmen ücretlere ilişkin çok sayıda istisna ve muafiyet hükmünün vergi harcamaları listesinde yer almadığı ve bu durumun hukuken muteber bir gerekçeye dayanmadığı görülmektedir. Bilhassa vergi kanunları dışındaki kanunlarda yer aldığı halde vergi harcamaları listesinde bulunmayan muafiyet ve istisna hükümlerinin standart vergi yapısının bir unsuru oldukları gerekçesine dayanılarak, vergi harcaması olarak kabul edilmediklerini söylemek bir hayli güçtür. Üstelik vergi harcamaları listesinde yer verilmeyen bu hükümlere mahiyetleri itibariyle çok benzeyen muafiyet ve istisna hükümlerinin vergi harcamaları listesinde yer alması çelişki doğurmaktadır. Bunun neticesinde, vergi harcamalarının bütçeye olan maliyeti gerçek tutarın çok altında hesap ve tahmin edilmektedir. Oysaki mali saydamlık, bütçe disiplini, bütçe amaç ve önceliklerine uyum ve fayda-maliyet analizi açısından bu tutarların olabildiğince doğru hesaplanmasında büyük yarar vardır.

Vergi harcamaları tanımına ilişkin doktrinde bir mutabakat olmakla birlikte, hangi muafiyet, istisna ve indirimlerin bütçe kanunları ekindeki vergi harcamaları listesinde yer alacağı hususunda uygulamada tereddüt ve belirsizlikler bulunmaktadır. Vergi bağışıklığı ve ayrıcalığı içeren hükümlerden hangilerinin vergi harcaması sayılması gerektiği hususunda yeknesak bir uygulamanın bulunmaması vergi harcamaları listesinde birbiri ile çelişen hükümlerin yer almasına sebebiyet vermektedir. Buna ek olarak, yürürlükte bulunmayan bazı ücret unsurlarına ilişkin vergi ayrıcalıkları vergi harcamaları listesinde yer alırken, ücretlere ilişkin negatif vergi harcamaları ile damga vergisi ve sosyal güvenlik kesintilerine ilişkin istisnalar vergi harcamaları listesinde yer almamaktadır. $\mathrm{Bu}$ durum vergi harcaması hesap ve tahminleri ile ülkeler arasındaki vergi harcamaları karşılaştırmalarının güvenilirliğini olumsuz etkilemektedir.

Devletin vergi bağışıklık ve ayrıcalıkları sebebiyle mahrum kaldığı gelir kaybını bilmesi ve bu tutarı kamuoyu ile paylaşması bakımından vergi harcamaları kapsamındaki tüm hükümleri içerecek şekilde vergi harcamaları listesi düzenlenmesinde yarar vardır. Ayrıca, vergi türleri itibariyle toplam vergi harcaması tahmini yerine, ücretler de dâhil olmak üzere her bir gelir unsuru için hesap ve tahmin yapılması, hatta ücretlerle ilgili her bir vergi harcaması kalemine ilişkin tutarın kamuoyu ile paylaşılması vergi harcamalarının bütçe ve vergi sistemi üzerindeki etkilerinin daha iyi tespit edilmesini ve kamuoyunun daha ayrıntılı bir biçimde bilgilendirilmesini mümkün k1lacaktır. 
Öztürk, İ. (2016), "Bütçe Kanununa Ekli Vergi Harcamaları Listesinin Mevzuatla Ücret Gelirlerine İlişkin Getirilen Muafiyet, İstisna ve İndirimler Bağlamında Analizi”, Sosyoekonomi, Vol. 24(27), 57-83.

Ücret gelirlerine yönelik muafiyet ve istisna hükümleri için "vergi harcaması" ve "standart vergi uygulaması" ayrımının son derece dikkatli ve gerekçeli olarak yapılması, kamu personel ücretlerine ilişkin vergi harcaması niteliğindeki muafiyet ve istisnalara vergi harcamaları listesinde, vergi harcaması hesap ve tahminlerinde yer verilmesi, ücretlerle ilgili daha sağlıklı vergi politikaları üretilmesine, bu politikaların başarısına, vergi harcamalarının maliyetlerini kontrol edebilme adına gerekli mekanizmaların geliştirilmesine katkı sağlayacaktır.

Tablo: 1

\section{Vergi Harcamaları Listesinde Yer Almayan Ücret Gelirlerine Yönelik Muafiyet ve İstisnaların Kanuni Dayanakları}

\begin{tabular}{|c|c|c|}
\hline Kanun Adı ve Numarası & Madde No & Madde Açıklaması \\
\hline 657 Sayılı Devlet Memurları Kanunu & 78 & Yurt dışında görevlendirilenlere yapılan ödemeler \\
\hline 657 Sayılı Devlet Memurları Kanunu & 91 & Kadrosu kaldırılan memurlara yapılan ödemeler \\
\hline 657 Sayılı Devlet Memurları Kanunu & 152 & Tazminatlar \\
\hline 657 Sayılı Devlet Memurları Kanunu & 156 & Fark ayliklar \\
\hline 657 Sayılı Devlet Memurları Kanunu & 203 & Aile yardımı ödeneği \\
\hline 657 Sayılı Devlet Memurları Kanunu & 208 & Ölüm yardımı \\
\hline 657 Sayılı Devlet Memurları Kanunu & Ek 26 & Makam tazminat \\
\hline 657 Sayılı Devlet Memurları Kanunu & Ek 32 & Öğretim yılına hazırlık ödeneği \\
\hline 657 Sayılı Devlet Memurları Kanunu & Ek 33 & Nöbet ücreti \\
\hline 657 Sayılı Devlet Memurları Kanunu & Ek 36 & $\begin{array}{l}\text { Türk kültürünü yayma amaçlı yurtdış1 } \\
\text { görevlendirilenlere yapılan ödemeler }\end{array}$ \\
\hline 657 Sayılı Devlet Memurları Kanunu & Geçici 39 & Sinıf değişme tazminatı \\
\hline 2802 Sayılı Hâkimler ve Savcılar Kanunu & 49 & $\begin{array}{l}\text { Hâkim ve savcılara Dışişleri Bakanlığı meslek } \\
\text { memurlarına ödenen "yurtdışı aylığı" esas alınarak } \\
\text { yapılacak ödeme }\end{array}$ \\
\hline 2802 Sayılı Hâkimler ve Savcılar Kanunu & 103 & Aylık ödemeler \\
\hline 2802 Sayılı Hâkimler ve Savcılar Kanunu & 106 & Yarg1 ödeneği ve ek ödeme \\
\hline $\begin{array}{l}6087 \text { Sayılı Hâkimler ve Savcılar Yüksek Kurulu } \\
\text { Kanunu }\end{array}$ & 34 & Ek tazminat \\
\hline $\begin{array}{l}\text { 2247Sayılı Uyuşmazlık Mahkemesinin Kuruluş ve } \\
\text { İşleyişi Hakkında Kanun }\end{array}$ & 38 & Toplantı ödeneği \\
\hline $\begin{array}{l}3717 \text { Sayılı Adli Personele ile Devlet Davalarını Takip } \\
\text { Edenlere Yol Gideri ve Tazminat Verilmesi Hakkında } \\
\text { Kanun }\end{array}$ & 2 & Yol tazminat1 \\
\hline 926 Sayılı Türk Silahlı Kuvvetleri Personel Kanunu & $49 / \mathrm{f}$ & Tazminatlar \\
\hline 926 Sayılı Türk Silahlı Kuvvetleri Personel Kanunu & 143 & Askeri öğrencilere ödenen harçliklar \\
\hline 926 Sayılı Türk Silahlı Kuvvetleri Personel Kanunu & 154 & Aile yardımı ödeneği \\
\hline 926 Sayılı Türk Silahlı Kuvvetleri Personel Kanunu & 177 & Ölüm yardım ödeneği \\
\hline 926 Sayılı Türk Silahlı Kuvvetleri Personel Kanunu & Ek 17 & Tazminatlar \\
\hline 926 Sayılı Türk Silahlı Kuvvetleri Personel Kanunu & Ek 18 & Makam tazminat1 \\
\hline $\begin{array}{l}4678 \text { Sayılı Türk Silahlı Kuvvetlerinde İstihdam } \\
\text { Edilecek Sözleşmeli Subay ve Astsubaylar Hakkında } \\
\text { Kanun }\end{array}$ & 18 & $\begin{array}{l}\text { Sözleşmeli subay ve sözleşmeli astsubaylara } \\
\text { ödenecek tazminat }\end{array}$ \\
\hline 3269 Sayılı Uzman Erbaş Kanunu & 16 & İkramiyeler \\
\hline 3466 Sayılı Uzman Jandarma Kanunu & 23 & Uzman jandarma adaylarına ödenecek harçlıklar \\
\hline $\begin{array}{l}500 \text { Sayılı Kıbrıs’a Gönderilecek Türk Askeri Birliği } \\
\text { Mensuplarının Aylık ve Ücretleriyle Çeşitli İstihkakları } \\
\text { ve Birliğin Başka Giderleri Hakkında Kanun }\end{array}$ & 1 & $\begin{array}{l}\text { Kuzey Kıbrıs Türk Cumhuriyeti'nde bulunan askeri } \\
\text { ve sivil personele yapılacak ödemeler }\end{array}$ \\
\hline 2914 Sayılı Yükseköğretim Personel Kanunu & 12 & Üniversite ödeneği \\
\hline 2914 Sayılı Yükseköğretim Personel Kanunu & 14 & Geliştirme ödeneği \\
\hline 2914 Sayılı Yükseköğretim Personel Kanunu & Ek 1 & Eğitim öğretim ödeneği \\
\hline
\end{tabular}


Öztürk, İ. (2016), "Bütçe Kanununa Ekli Vergi Harcamaları Listesinin Mevzuatla Ücret Gelirlerine İlişkin Getirilen Muafiyet, İstisna ve İndirimler Bağlamında Analizi”, Sosyoekonomi, Vol. 24(27), 57-83.

\begin{tabular}{|c|c|c|}
\hline 2914 Sayılı Yükseköğretim Personel Kanunu & Ek 2 & Makam tazminat, \\
\hline 2914 Sayıl1 Yükseköğretim Personel Kanunu & Geçici 2 & Fark ödemeler \\
\hline 2914 Sayılı Yükseköğretim Personel Kanunu & Geçici 3 & Yükseköğretim tazminatı \\
\hline 2914 Sayıl1 Yükseköğretim Personel Kanunu & Geçici 2 & Akademik teşvik ödemesi \\
\hline 4652 Sayılı Polis Yüksek Öğretim Kanunu & $25 / \mathrm{c}$ & Ek ödeme \\
\hline $\begin{array}{l}4505 \text { Sayılı Sosyal Güvenlikle İlgili Bazı Kanunlarda } \\
\text { Değișiklik Yapılması ve Temsil Tazminatı Ödenmesi } \\
\text { Hakkında Kanun }\end{array}$ & 5 & Temsil tazminatı \\
\hline 6362 Sayılı Sermaye Piyasası Kanunu & 131 & Emsali personele yapılan ödemeler \\
\hline 5411 Sayılı Bankacılık Kanunu & 102 & Ücret ve tazminatlar \\
\hline 5411 Sayılı Bankacılık Kanunu & 125 & Ücret ve tazminatlar \\
\hline $\begin{array}{l}\text { 5176 Sayılı Kamu Görevlileri Etik Kurulu Kurulması } \\
\text { ve Bazı Kanunlarda Değişiklik Yapılması Hakkında } \\
\text { Kanun }\end{array}$ & 2 & Huzur hakk1 \\
\hline $\begin{array}{l}298 \text { Sayılı Seçimlerin Temel Hükümleri ve Seçmen } \\
\text { Kütükleri Hakkında Kanun }\end{array}$ & 182 & Gündelikler \\
\hline 2935 Sayılı Olağanüstü Hal Kanunu & 29 & Fazla çalışma ücreti \\
\hline 1402 Sayıl1 S1kıyönetim Kanunu & 26 & S1kıyönetim hizmet zammı \\
\hline $\begin{array}{l}\text { 6004 Sayılı Dışişleri Bakanlığının Kuruluş ve Görevleri } \\
\text { Hakkında Kanun }\end{array}$ & 18 & Tazminat \\
\hline 3201 Sayılı Emniyet Teşkilatı Kanunu & 55 & Kadrosuzluk tazminatı \\
\hline 3201 Sayılı Emniyet Teşkilatı Kanunu & Ek 21 & Fazla çalışma ücreti \\
\hline 3201 Sayılı Emniyet Teşkilatı Kanunu & Ek 26 & Bomba imha tazminat 1 \\
\hline $\begin{array}{l}3671 \text { Sayılı TBMM Üyelerinin Ödenek Yolluk ve } \\
\text { Emekliliklerine Dair Kanun }\end{array}$ & 1 & TBMM üyelerinin aylık ödenekleri \\
\hline $\begin{array}{l}6216 \text { Sayılı Anayasa Mahkemesinin Kuruluşu ve } \\
\text { Yargılama Usulleri Hakkında Kanun }\end{array}$ & 31 & $\begin{array}{l}\text { Geçici olarak Anayasa Mahkemesi'nde } \\
\text { görevlendirilenlere ödenecek maaş farkları }\end{array}$ \\
\hline $\begin{array}{l}2863 \text { Sayılı Kültür ve Tabiat Varlıklarını Koruma } \\
\text { Kanunu }\end{array}$ & Ek 2 & Bakan tarafindan belirlenen ödeme \\
\hline 4054 Sayılı Rekabetin Korunması Hakkında Kanun & 37 & Rekabet Kurulu başkan ve üyelerinin aylık ücretleri \\
\hline $\begin{array}{l}5434 \text { Sayılı Türkiye Cumhuriyeti Emekli Sandığ } 1 \\
\text { Kanunu }\end{array}$ & Ek 77 & $\begin{array}{l}\text { Harp veya vazife malullüğü aylı̆̆ } \text { üzerinden aylık } \\
\text { bağlananlara yapılan ödemeler }\end{array}$ \\
\hline $\begin{array}{l}5434 \text { Sayılı Türkiye Cumhuriyeti Emekli Sandığ } 1 \\
\text { Kanunu }\end{array}$ & Ek 79 & $\begin{array}{l}\text { Harp veya vazife malullüğü aylığı üzerinden aylık } \\
\text { bağlananlara yapılan ek ödemeler }\end{array}$ \\
\hline $\begin{array}{l}2629 \text { Sayılı Uçuş, Paraşüt, Denizaltı, Dalgıç ve } \\
\text { Kurbağa Adam Hizmetleri Tazminat Kanunu }\end{array}$ & 17 & Aylık tazminatlar \\
\hline $\begin{array}{l}3160 \text { Sayılı Emniyet Teşkilatı Uçuş ve Dalış Hizmetleri } \\
\text { Tazminat Kanunu }\end{array}$ & $6 / \mathrm{e}, \mathrm{f}$ & Tazminatlar \\
\hline 4734 Sayılı Kamu İhale Kanunu & $56 / 6$ & $\begin{array}{l}\text { İhtisas sahibi kamu veya özel hukuk tüzel kişileri ile } \\
\text { gerçek kişilere yapılan ödemeler }\end{array}$ \\
\hline 2108 Sayılı Muhtar Ödenek ve Sosyal Güvenlik Yasası & 1 & Aylık ödenek \\
\hline $\begin{array}{l}399 \text { Sayılı Kamu İktisadi Teşebbüsleri Personel } \\
\text { Rejiminin Düzenlenmesine Dair KHK }\end{array}$ & Ek 2 & Havacılık tazminatı \\
\hline $\begin{array}{l}\text { 631 Sayılı Memurlar ve Diğer Kamu Görevlilerinin } \\
\text { Mali ve Sosyal Haklarında Düzenlemeler ile Bazı } \\
\text { Kanun ve KHK'lerde Değişiklik Yapılması Hakkında } \\
\text { KHK }\end{array}$ & 14/A & Harcırah yerine ödenen tazminatlar \\
\hline 270 Sayılı Yüksek Hâkimlik Tazminatı Hakkında KHK & 1 ve 3 & Yüksek hâkimlik tazminatı \\
\hline $\begin{array}{l}375 \text { Sayılı Devlet Memurları ve Diğer Kamu } \\
\text { Görevlilerine Memuriyet Taban Aylığ } 1 \text { ve Kıdem } \\
\text { Aylığı ile Ek Tazminat Ödenmesi Hakkında KHK }\end{array}$ & $1 / \mathrm{C}-4$ & Görev tazminat 1 \\
\hline $\begin{array}{l}375 \text { Sayılı Devlet Memurları ve Diğer Kamu } \\
\text { Görevlilerine Memuriyet Taban Aylığı ve Kıdem } \\
\text { Aylığı ile Ek Tazminat Ödenmesi Hakkında KHK }\end{array}$ & 2 & Yabanc1 dil tazminatı \\
\hline 375 Sayılı KHK & 28 & Ek tazminatlar \\
\hline $\begin{array}{l}375 \text { Sayılı Devlet Memurları ve Diğer Kamu } \\
\text { Görevlilerine Memuriyet Taban Aylığı ve Kıdem } \\
\text { Aylığı ile Ek Tazminat Ödenmesi Hakkında KHK }\end{array}$ & Ek 4 & Toplu sözleşme ikramiyesi \\
\hline
\end{tabular}


Öztürk, İ. (2016), "Bütçe Kanununa Ekli Vergi Harcamaları Listesinin Mevzuatla Ücret Gelirlerine İlişkin Getirilen Muafiyet, İstisna ve İndirimler Bağlamında Analizi”, Sosyoekonomi, Vol. 24(27), 57-83.

\begin{tabular}{|c|c|c|}
\hline $\begin{array}{l}375 \text { Sayılı Devlet Memurları ve Diğer Kamu } \\
\text { Görevlilerine Memuriyet Taban Aylığı ve Kıdem } \\
\text { Aylığı ile Ek Tazminat Ödenmesi Hakkında KHK }\end{array}$ & Ek 8 & Aile yardımı ödeneği \\
\hline $\begin{array}{l}375 \text { Sayılı Devlet Memurları ve Diğer Kamu } \\
\text { Görevlilerine Memuriyet Taban Aylığı ve Kıdem } \\
\text { Aylığı ile Ek Tazminat Ödenmesi Hakkında KHK }\end{array}$ & Ek 9 & Ek ödeme \\
\hline $\begin{array}{l}375 \text { Sayılı Devlet Memurları ve Diğer Kamu } \\
\text { Görevlilerine Memuriyet Taban Aylığı ve Kıdem } \\
\text { Aylığı ile Ek Tazminat Ödenmesi Hakkında KHK }\end{array}$ & Ek 10 & Tazminatlar \\
\hline $\begin{array}{l}375 \text { Sayılı Devlet Memurları ve Diğer Kamu } \\
\text { Görevlilerine Memuriyet Taban Aylığı ve Kıdem } \\
\text { Aylığı ile Ek Tazminat Ödenmesi Hakkında KHK }\end{array}$ & Ek 13 & Fazla çalışma ücreti \\
\hline $\begin{array}{l}375 \text { Sayılı Devlet Memurları ve Diğer Kamu } \\
\text { Görevlilerine Memuriyet Taban Aylığı ve Kıdem } \\
\text { Aylığı ile Ek Tazminat Ödenmesi Hakkında KHK }\end{array}$ & Ek 14 & $\begin{array}{l}\text { Cumhurbaşkanı, TBMM Başkanı ve Başbakanın } \\
\text { yakın koruma ve makam hizmetlerinde görev yapan } \\
\text { personele yapılan ilave ek ödeme }\end{array}$ \\
\hline $\begin{array}{l}4490 \text { Sayılı Türk Uluslararası Gemi Sicili Kanunu ile } \\
491 \text { Sayılı KHK'de Değişiklik Yapılmasına Dair Kanun }\end{array}$ & 12 & $\begin{array}{l}\text { Türk Uluslararası Gemi Sicilinde kayıtlı gemilerde ve } \\
\text { yatlarda çalışan personele ödenen ücretler }\end{array}$ \\
\hline 4447 Sayılı İşsizlik Sigortası Kanunu & 50 & İşsizlik ödeneği \\
\hline 4447 Sayılı İşsizlik Sigortası Kanunu & Geçici 12/a & İşsizlik Sigortası Fonundan yapılan aylık ödemeler \\
\hline 5580 Sayılı Özel Öğretim Kurumları Kanunu & 9 & Sosyal yardım kapsamında yapılan ek ödemeler \\
\hline $\begin{array}{l}2809 \text { Sayılı Yükseköğretim Kurumları Teşkilatı } \\
\text { Kanunu }\end{array}$ & Geçici 3 & $\begin{array}{l}\text { Tıpta uzmanlık ögrenimi yapanlara ödenen fark } \\
\text { tazminat ödemeler }\end{array}$ \\
\hline 6100 Sayılı Hukuk Muhakemeleri Kanunu & 265 & Mahkeme tarafından çağrılan tanığa ödenen ücretler \\
\hline 5271 Sayılı Ceza Muhakemesi Kanunu & 61 & Çağrılan tanığa ödenecek tazminat \\
\hline
\end{tabular}

Not: Yürürlükteki kanunların tetkiki neticesinde düzenlenmiştir.

\section{Kaynaklar}

Abell, A. \& B. Bernanke (1994), Macroeconomics, Addison-Wesley Publishing Company, New York.

Akdoğan, A. (2007), Kamu Maliyesi, Gazi Kitabevi, Ankara.

Akdoğan, A. (2009), Vergi Hukuku ve Türk Vergi Sistemi, Gazi Kitabevi, Ankara.

Arslan, M. (2004), Türk Vergi Sistemi, Nobel Yayın Dağıtım.

Balkan, G. (1976), Ücret Sistemleri, Ege Üniversitesi Mühendislik Bilimleri Fakültesi Yayınları.

Bratic, V. (2006), Tax Expenditures: A Theoretical Review, Institute of Public Finance, Zagreb.

Bulutoğlu, K. (2004), Türk Vergi Sistemi, Batı Türkeli Yayıncılı.

Coşkun, Z. (2010), "Tax Expenditures in the European Union and Turkey”, Orta Doğu Teknik Üniversitesi Sosyal Bilimler Enstitüsü, Yüksek Lisans Tezi, Ankara.

Çakır, Ö. (2006), Ücret Adaletinin İş Davranışları Üzerindeki Etkileri, Kamu İşletmeleri İşverenleri Sendikası Yayını.

Erdem, M. \& D. Şenyüz \& İ. Tatlığlu (2013), Kamu Maliyesi, Ekin Basım Yayın Dağıtım, Bursa.

European Centre for the Development of Vocational Training (2009), Using Tax Incentives to Promote Educationand Training.

Ferhatoğlu, E. (2005), "Bir Kamu Harcaması Türü Olarak Vergi Harcaması ve Türk Kurumlar Vergisi Açısından Değerlendirilmesi”, Osmangazi Üniversitesi Sosyal Bilimler Dergisi, 2(6), 77-93.

Freeland, J. \& S. Lind \& R. Stephens (1996), Fundamentals of Federal Income Taxation, The Foundation Press, New York. 
Gerek, S. (1999), Türkiye'de Asgari Ücretler ve Enflasyon, Anadolu Üniversitesi Yayınları.

Giray, F. (2002), "Vergi Harcamaları: Harcama Vergileri Açısından Analizi”, Uludağ Üniversitesi İktisadi ve İdari Bilimler Fakültesi Dergisi, 1(21), 27-52.

Gönül, H.H. (2002), "Vergi Harcamaları II”, Yaklaşım, 112, 68-72.

Gözler, K. (2009), İdare Hukuku, Ekin Basım Yayın Dağıtım, Bursa.

Gruber J. (2005), Public Finance and Public Policy, Worth Publishers, New York.

Hicks, J.R. (1968), TheTheory of Wages, Macmillan.

Kızılot, Ş. \& M. Taş (2011), Vergi Hukuku ve Türk Vergi Sistemi, Yaklaşım Yayıncılık, Ankara.

Korkmaz, E. (1998), İktisadi Gelişme ve Mali Sistem, Filiz Kitabevi, İstanbul.

Korkmaz, A. \& A. Turan \& A. Turunç (1985), Ücret ve İstihdam Başlıca Yaklaşımlar ve Planlı Dönemdeki Gelişmeler, Milli Prodüktivite Merkezi Yayınları.

Levinson, M. (2006), Guide to Financial Markets, Bloomberg Press, New York.

Maliye Bakanlığı Gelir Politikaları Genel Müdürlüğü (2007), Vergi Harcamaları Raporu, Ankara.

Mikesell, J. (1995), Financial Administration: Analysis and Applications for the Public Sector, Wadswort Publishing Company, Belmont.

Mishkin, F. (1986), The Economics of Money, Bankingand Financial Markets, Little Brown and Company, Boston.

Musgrave, R. \& P. Musgrave (1989), Public Finance in Theory and Practice, Literatür Yayıncılık, İstanbul.

Öncel, M. \& N. Çağan (2003), Bankacılar İçin Mali Hukuk Bilgisi, Banka ve Ticaret Hukuku Araştırma Enstitüsü Yayınları, Ankara.

Öncel, M. \& A. Kumrulu \& N. Çağan (2013), Vergi Hukuku, Turhan Kitabevi, Ankara.

Öz, N.S. (2006), Gelir Vergisinde Vergiyi Doğuran Olay, Maliye ve Hukuk Yayınları.

Özel, H. \& D. Şenyüz (1987), Türk Vergi Sistemi (Gelir Vergisi), Uludağ Üniversitesi Basımevi.

Öztürk, İ. \& C.G. Sabuncu (2012), Türk Sermaye Piyasasında Vergi Harcamaları, İAB Yayınları, İstanbul.

Parasız, İ. (1994), Ücret Teorisi (Modern Yaklaşım), Ezgi Kitapevi.

Pedük, T. (2005), “Dünyada ve Türkiye'de Vergi Harcamalar1”, Trakya Üniversitesi Sosyal Bilimler Enstitüsü Maliye Anabilim Dalı Yüksek Lisans Tezi, Edirne.

Rosen, H. (1985), Public Finance, Irwin Publishing, Illinois.

Slavin, S. (1999), Macroeconomics, IrwinMcGraw-Hill, New York.

Surrey, S.S. \& P.R. McDaniel (1985), Tax Expenditures, Harvard University Press.

Starrett, D. (1988), Foundations of Public Economics, Cambridge University Press, Cambridge.

Stigliz J.E. (1986), Economics of the Public Sector, W.W. Norton \& Company.

Stiglitz, J.E. (1994), Kamu Kesimi Ekonomisi, Çeviren: Ömer Faruk Batırel, Marmara Üniversitesi Yayın No: 549, İktisadi ve İdari Bilimler Fakültesi Yayınları, İstanbul.

Stiglitz, J.E. (1999), Economics of the Public Sector, W. W. Norton \&Company.

Türk, İ. (2011), Kamu Maliyesi, Turhan Kitabevi, Ankara.

Tresch, R. (2002), Public Finance: A Normative Theory, Acedemic Press, San Diego. 
Öztürk, İ. (2016), "Bütçe Kanununa Ekli Vergi Harcamaları Listesinin Mevzuatla Ücret Gelirlerine İlişkin Getirilen Muafiyet, İstisna ve İndirimler Bağlamında Analizi”, Sosyoekonomi, Vol. 24(27), 57-83.

Wolf, P. (1965), Wages and Labour Mobility, OECD.

Y1lmaz, A. (2007), “Türkiye'de Vergi Sistemi ve Uygulanan Vergi Politikaları”, Planlama Uzmanlığ Tezi, T.C. Başbakanlık Devlet Planlama Teşkilatı Müsteşarlığı Yıllık Programlar ve Konjonktür Değerlendirme Genel Müdürlüğü, Ankara. 
Öztürk, İ. (2016), "Bütçe Kanununa Ekli Vergi Harcamaları Listesinin Mevzuatla Ücret Gelirlerine İlişkin Getirilen Muafiyet, İstisna ve İndirimler Bağlamında Analizi”, Sosyoekonomi, Vol. 24(27), 57-83. 